\title{
GROUNDWATER CHARACTERISTICS ASSESSMENT IN KURDISTAN REGION PROVINCES-IRAQ: A REVIEW
}

\author{
Dara Muhammad Hawez ${ }^{*}$, Nashwan Shawkat Mizzouri ${ }^{* *}$, Shuokr Qarani AZiz ${ }^{* * *}$, \\ JWAN SABAH MUSTAFA ${ }^{* * * *}$ and SHWANA BRAIM HASSAN MANGURI ${ }^{* * * * * *}$ \\ "Dept. of Civil Engineering, Faculty of Engineering, Koya University, Koya \\ Kurdistan Region-Iraq \\ ${ }^{* *}$ Dept. of Civil Engineering, College of Engineering, University of Duhok, Kurdistan Region-Iraq \\ ${ }^{* * * *}$ Dept. of Civil Engineering, College of Engineering, University of Salahaddin-Erbil, \\ Kurdistan Region-Iraq \\ ***** General Directorate of Dams and Reservoirs, Ministry of Agriculture and Water Resources, Erbil, \\ Kurdistan Region-Iraq \\ ${ }^{* * * * * *}$ Dept. of Civil Engineering, University of Raparin, Sulaymaniyah, Kurdistan Region-Iraq
}

(Accepted for Publication: December 8, 2020)

\begin{abstract}
Over the past decades, drilling wells and groundwater extraction for agricultural, domestic, and industrial purposes is growing at a high rate in Kurdistan Region-Iraq, meaning that groundwater becomes one primary water source. Increased demand for water and over-exploitation and unsustainable practices severely deteriorate groundwater. Therefore, it is essential to monitor the water quality. In the past years, many papers have been published on groundwater quality in the Kurdistan Region. Thus, this research aims to review, evaluates and summarizes the results of published papers concerning groundwater characteristics in Erbil, Suliamni, Duhok, and Halabja, Governorates. This work targets about thirty published papers. These papers focused on Wells, Springs, and karizes (qanats) as groundwater. The water testes have taken from different cities and locations in these three governorates. The reviewed studies considered a number of water parameters and chemical elements, such as physicochemical parameters, heavy metals, and radioactive substances. This work assesses water quality parameters from reviewed studies and illustrates the comment parameters by the spatial distribution mapped using the kriging method. Generally, the groundwater polluted in some zones in the Kurdistan Region and normally it can be used for drinking and domestic uses after the disinfection process.
\end{abstract}

KEYWORDS: Groundwater, characteristics, drinking water, kriging method, Kurdistan Region, Iraq,

\section{INTRODUCTION}

I n many countries, groundwater is an essential water source for domestic, agricultural, and industrial use. In recent decades, demand for freshwater has risen sharply due to the rapid population growth and the fast development of industrialization (Gebrehiwot et al., 2011; Lanjwani et al., 2019).As a result of that, and insufficient amount of surface water, need for groundwater resources multiplied for drinking , agriculture, and world industrial

dara.muhammad@koyauniversity.org,dara.hawez@gmail.com; Nashwan.shawkat@uod.ac: shuokr.aziz@su.edu.krd,shoker71@yahoo.com; juan.sabah@yahoo.com;

shwana.manguri@uor.edu.krd ${ }^{1}$ Corresponding author Department of Civil Engineering, Faculty of 
purposes (Rajappa et al., 2011; Rao et al., 2012) . Almost thirty percent of the world's population is supposed to drink from groundwater (Nickson et al., 2005). However, groundwater forms (5\% to $7 \%$ ) of the water resources of Iraq, several villages, districts, and cities use groundwater as a main source of drinking water and agriculture purpose (Al-Ansari et al., 2014). In addition, groundwater has been used recently significantly in the oil and gas sector in Kurdistan Region. Therefore, problems related to groundwater quality and management have to be given further consideration.

In Iraqi Kurdistan, the extraction of groundwater for farming purposes is increasing at an unsustainable rate, indicating that withdrawals pass the natural recharge rate of underground aquifers. Traditional irrigation systems are not efficient; these need more water conduce to over-extraction of groundwater, and insufficient rainfall in the area affects rain-fed agriculture. According to official sources, over seventy percent of farmers depend on shallow wells (Tinti, 2017). Besides that, residences in cities, towns, and villages depend on drilled wells for domestic purposes. Also, the majority of industries mainly used groundwater in their production. Therefore, studying the groundwater resources and its potential pollution in the area becomes a necessity (Abdullah et al., 2016).

Protection the groundwater quality is important, the major approach to the protection of groundwater is the monitoring and estimate of the chemical, physical and biological substances of it (Jang et al., 2013). Monitoring groundwater and collecting data from the process of monitoring provides an understanding of the situation of groundwater (Júnez-Ferreira \& Herrera, 2013; Mogheir et al., 2006). An excellent monitoring scheme would suggest both accurate and sufficient groundwater property data as well as cost-effectively fair data (Baalousha, 2010). However, a monitoring network could be improved by taking more samples, this may lead to spending more money and provide unnecessary information (Narany et al., 2014). As a result of that, collecting and reviewing the groundwater data has outstanding benefits to understand the overall condition of groundwater and helps monitoring process.

Potential groundwater zones were created by allocating importance to each parameter and mapping the data using the Spatial Interpolation Technique. The accuracy methods of interpolation were used in spatially predicting soil and water qualities in numerous studies (Robinson \& Metternicht, 2006). Mehrjardi et al. (2008) using Kriging ,Inverse Distance Weighting (IDW), and Cokriging methods to estimate spatial distribution of groundwater properties. Istok and Cooper (1988) used applied Kriging method to evaluate heavy metals .D'Agostino et al. (1998) used spatial distribution Kriging and Cokriging methods for determine nitrate concentrations in an aquifer. Mouser and Rizzo (2004)utilized geostatistics for investigating groundwater quality.

This study involved the analysis of Physico-chemical, heavy metals, radioactive substances, and some biological parameters. The data were collected from thirty existing studies from the Kurdistan Region (Erbil, Sulaimani, Duhok, and Halabja Provinces). The characterizes from these studies evaluate to identify their suitability water for drinking water. The purpose of this study is to critique, evaluate, and summarize the results from the issued articles regarding groundwater. This study uses the kriging method to assess and predict some groundwater quality parameters for particular areas.

Through the current investigation, USEPA, WHO, and Canadian Drinking Water Quality

dara.muhammad@koyauniversity.org,dara.hawez@gmail.com; Nashwan.shawkat@uod.ac: shuokr.aziz@su.edu.krd,shoker71@yahoo.com; juan.sabah@yahoo.com; shwana.manguri@uor.edu.krd ${ }^{1}$ Corresponding author Department of Civil Engineering, Faculty of Engineering, Koya University Koya KOY45, Kurdistan Region - F.R. Iraq 
standards used for comparison and evaluating the groundwater in the Kurdistan Region for its suitability for domestic demand. The study identified many low water quality cities that can be used to know sources of pollution, thereby encouraging city authorities to take necessary precautionary strategies to prevent the groundwater pollution.

\section{MATERIALS AND METHODS}

Water samples were collected and tested in all four Provinces of the Kurdistan Region to evaluate groundwater quality. Samples were taken in a different groundwater source, such as wells springs and, Karizes (Qanats). The Studies are listed in Tables 1 to 3 .

\subsection{Study Area}

The Iraqi Kurdistan Region is placed in the northern portion of Iraq. It consists of four governorates, Erbil (the region's capital), Suliamni, Duhok, and Halabja. Groundwater quality in theses Provinces has been studied work No. 1 to No. 12 in Table 1 was conducted in Erbil Province. Table 2 studies Nos. 1 to 13 were carried out on groundwater quality in
Sulaimani and Halabja provinces. The last five articles in Table 3 are studies in Duhok province.

\subsubsection{Erbil Province}

Researchers worked on groundwater quality in and around Erbil's city, using twelve studies in different places during the period 1998-2018.

Aziz \& Fakhrey (2016) investigated the effects of Kawergosk oil refinery on the Greater-Zab River (GZR) and the groundwater in Khabat District. Kawergosk oil refinery lies in Khabat District (Fig. 1). The second study for Erbil Province was one by Aziz \& Maulood (2015) studied hazards created from anaerobic landfill leachate at Erbil Landfill Site (ELS). The water samples were obtained from groundwater near ELS and the Salahaddin University in Erbil College of Engineering (Table 1 and Fig. 1). Furthermore, groundwater at Erbil Landfill Site (ELS) (Erbil Dumpsite area) has studied by Gardi, S. Q. (2017), in two separate articles. The author took water samples from three wells around the Erbil Landfill Site (Tashyapi Kani Qirzhala and QaryaTagh) to assess the environmental impact of unsafe and uncontrolled waste disposal practices in Erbil dumpsite (Fig.1).

Table (1): Studies in Erbil Province

\begin{tabular}{|c|c|c|c|c|}
\hline No & Purpose & Authors & $\begin{array}{c}\text { Year of } \\
\text { publication }\end{array}$ & Area of study \\
\hline 1 & $\begin{array}{l}\text { Study of the characterization of Karergosk oil refinery } \\
\text { wastewater, GZR and groundwater near Kawergosk Refinery } \\
\text { and demonstrate the effect of waste water on surrounding } \\
\text { water sources in Kawergosk area. }\end{array}$ & $\begin{array}{l}\text { Shuokr Qarani Aziz and } \\
\text { Enas sa'ad Fakhrey }\end{array}$ & 2016 & $\begin{array}{l}\text { Kawergosk Refinery, Erbil City } \\
\text { taken from Agulan and Jadida well. }\end{array}$ \\
\hline 2 & $\begin{array}{l}\text { Identify the risks posed by anaerobic landfill leachate from the } \\
\text { Erbil Landfill Site (ELS) to groundwater and observe the } \\
\text { effects of municipal solid waste disposal (MSW) on soil } \\
\text { properties. }\end{array}$ & $\begin{array}{l}\text { Shuokr Qarani Aziz and } \\
\text { Yousif Ismael Maulood }\end{array}$ & 2015 & $\begin{array}{l}\text { Municipal solid waste landfill (near } \\
\text { Kani- Qrzhala Sub-district) }\end{array}$ \\
\hline 3 & $\begin{array}{l}\text { Monitoring of water quality variations in Erbil City through a } \\
\text { year. }\end{array}$ & Shuokr Qarani Aziz & 2004 & Erbil city -Iskan (Well No.3) \\
\hline 4 & Assessing the suitability of ten well waters for drinking & Janan Jabbar Toma & 2006 & Ainkawa, Erbil City (Ten wells in \\
\hline
\end{tabular}

dara.muhammad@koyauniversity.org,dara.hawez@gmail.com; Nashwan.shawkat@uod.ac: shuokr.aziz@su.edu.krd,shoker71@yahoo.com; juan.sabah@yahoo.com; shwana.manguri@uor.edu.krd ${ }^{1}$ Corresponding author Department of Civil Engineering, Faculty of Engineering, Koya University Koya KOY45, Kurdistan Region - F.R. Iraq 


\begin{tabular}{|c|c|c|c|c|}
\hline & purposes in Ainkawa District. & & & Ainkawa) \\
\hline 6 & $\begin{array}{l}\text { Find the water quality of the } 20 \text { springs and wells selected in } \\
\text { the Soran district to analyze the physical and chemical quality } \\
\text { of the well and spring water, and find the various } \\
\text { concentrations of samples collected in wells and spring. }\end{array}$ & $\begin{array}{l}\text { M R A Al-Barwary1, R A } \\
\text { Meshabaz1, N J } \\
\text { Hussein1, and N H Ali1 }\end{array}$ & 2018 & $\begin{array}{l}\text { Soran District (twenty Wells and } \\
\text { twenty Springs) }\end{array}$ \\
\hline 7 & $\begin{array}{l}\text { Data study for spring hammam jalli systematically collected } \\
\text { over a year. }\end{array}$ & $\begin{array}{l}\text { Mohammed H. S. } \\
\text { Zangana }\end{array}$ & 2015 & $\begin{array}{l}\text { Hammam Jalli's Spring Water at } \\
\text { Koya District }\end{array}$ \\
\hline 8 & $\begin{array}{l}\text { Understand the quality and quantity of water in the city of } \\
\text { Erbil. }\end{array}$ & $\begin{array}{l}\text { Saima Jadoon, } \\
\text { Sarfaraz Munir, and } \\
\text { Iftikhar Fareed }\end{array}$ & 2015 & Erbil City (Five Wells) \\
\hline 10 & $\begin{array}{l}\text { Preventing and keeping people safe from possible communal } \\
\text { waste infections and contamination. }\end{array}$ & $\begin{array}{l}\text { Sirwa Qader Smail } \\
\text { Gardi }\end{array}$ & $2017 a$ & $\begin{array}{l}\text { Erbil Dumpsite area: three water } \\
\text { wells (Tashyapi Kani-Qirzhala and } \\
\text { QaryaTagh) }\end{array}$ \\
\hline 11 & $\begin{array}{l}\text { Use of electrical resistivity method as an instrument for } \\
\text { assessing the contamination impact. }\end{array}$ & Sirwa Qader S. Gardi & $2017 b$ & $\begin{array}{l}\text { Erbil Dumpsite area: three water } \\
\text { wells (Tashyapi Kani-Qirzhala and } \\
\text { QaryaTagh) }\end{array}$ \\
\hline 12 & $\begin{array}{l}\text { Assessment of the water quality index (WQI) for the six wells } \\
\text { in the town of Erbil }\end{array}$ & $\begin{array}{l}\text { Janan J. Toma, Zhalla } \\
\text { S. Assad and Dnya R. } \\
\text { Baez }\end{array}$ & 2013 & $\begin{array}{l}\text { Erbil City, six wells (Tayrawa 1, } \\
\text { Azadi 8, Ronaky 1, Rizgari 1, } \\
\text { Badawa 13, Ankawa 9) }\end{array}$ \\
\hline
\end{tabular}

Aziz did another study in (2004) to examine the seasonal variation of water and wastewater in Erbil, for groundwater. The author took samples from well No.3 in Iskan Quarter and found there is no noticeable change in its quality in wells through the year; therefore, Aziz suggested taking samples from wells once or twice a year. Besides, various sections of Erbil city groundwater have been investigated. Toma (2006) assessed ten wells' suitability for drinking purposes in the Ainkawa area. and it found that with compared to international standards all wells in this investigation are suitable for drinking purposes. Toma et al. (2013) examined the water quality index (WQI) for the six-well in various quarters of Erbil City (Ronaky 1, Tayrawa 1, Badawa 13, Azadi 8, Rizgari 1, and Ankawa 9). The results showed that the quality of water is suitable for drinking. Furthermore, at Erbil city, Fifty Wells were tested by Daham et al. (1998). The paper recorded a high $\mathrm{pH}$, turbidity, total hardness, and alkalinity in Erbil City. Also, in Bakhtiari and Ainkawa quarters, five wells checked by Jadoon et al. (2015). By testing all five wells, authors found that water from the wells is also subject to significant contaminants such as high concentration nitrates and pathogens (Table 1 and Fig. 1).

Outside Erbil city, Groundwater Koya and Soran Districts are assessed by Babir and Ali (2016), Zangana et al. (2014), and Al-Barwary et al. (2018). Babir and Ali (2016) investigated Thirty wells and three springs at Koya Basin. It was stated that some wells and springs have a high value of Sulfate,

dara.muhammad@koyauniversity.org,dara.hawez@gmail.com; Nashwan.shawkat@uod.ac: shuokr.aziz@su.edu.krd,shoker71@yahoo.com; juan.sabah@yahoo.com;

shwana.manguri@uor.edu.krd ${ }^{1}$ Corresponding author Department of Civil Engineering, Faculty of Engineering, Koya University Koya KOY45, Kurdistan Region - F.R. Iraq 
Electrical conductivity, and TDS. This may happen due to existing gypsum and thick beds of claystone in the formation of the area. Further, Hammam Jalli's Spring studied as a thermal spring at Koya District (Table 1 and Fig. 1). Zangana et al. (2014) presented that Both the $\mathrm{pH}$ of the water of hammam jalli springs and the conductivity are in the allowable ranges of drinking water, and the Hammam Jalli's water has low mineral contents. At Soran District, Al-Barwary et al. (2018) collected water samples from twenty springs and twenty wells. The results showed that eight wells and four springs' water samples require treatment for drinking practices (Table 1 and Fig. 1).

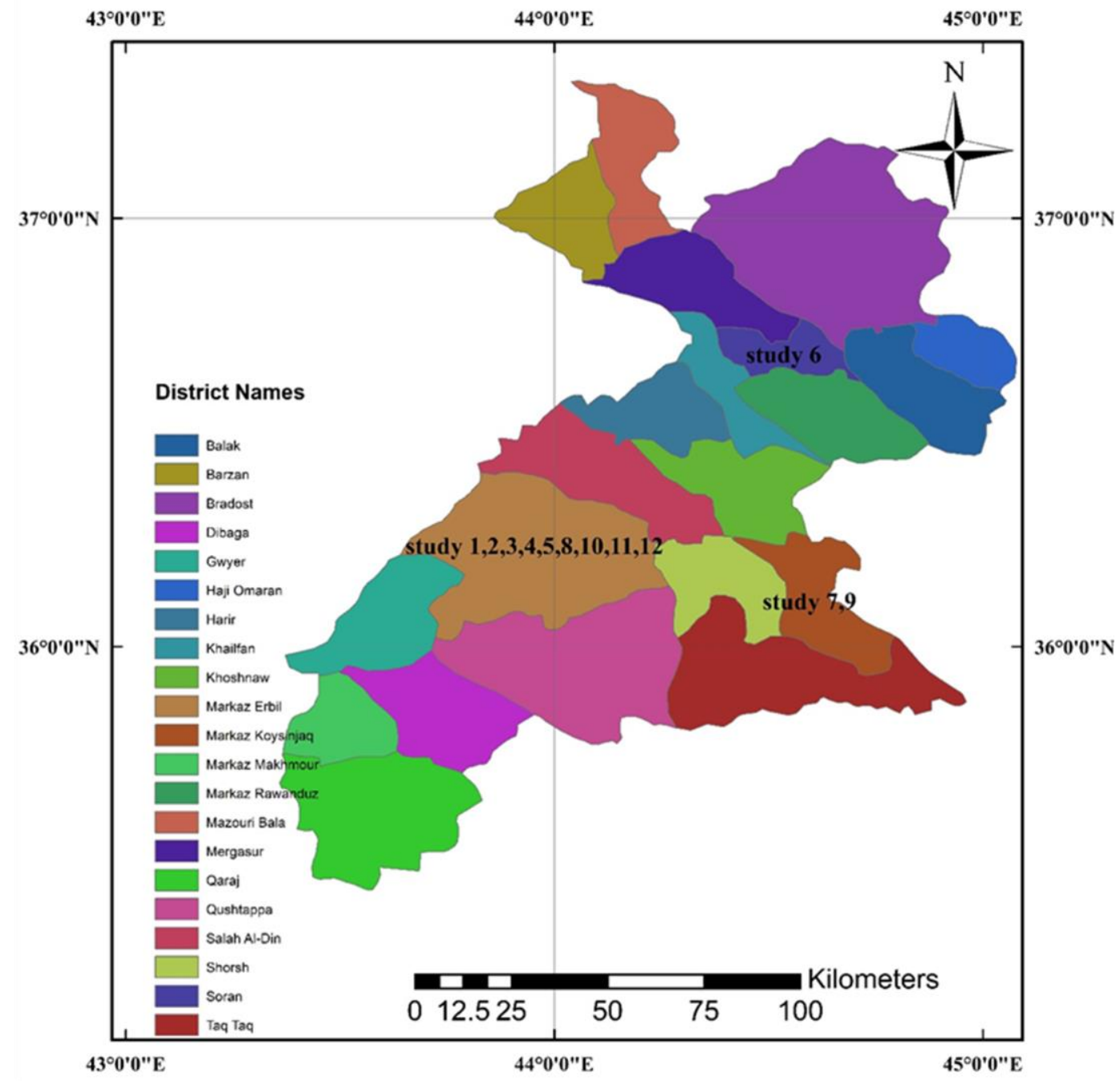

Fig. (1): Erbil Province

\subsubsection{Sulimani and Halabja Provinces}

Scholars studied groundwater status in
Sulimani and Halabja provinces, and some of their districts, though thirteen articles between

dara.muhammad@koyauniversity.org,dara.hawez@gmail.com; Nashwan.shawkat@uod.ac: shuokr.aziz@su.edu.krd,shoker71@yahoo.com; juan.sabah@yahoo.com; 


\section{7 and 2019, Table 2.}

Groundwater in Sulimani City has different sources such as spring, wells, and karizes (qanat). The scholars investigated the groundwater sources in Sulimani for a different purpose in various articles. Al-Manmi et al. (2019) focused on the current situation of nine karizes in Sulimani and their deteriorated construction regarding the building and water quality. Further, Al-Manmi and Saleh (2019) inspected three large springs in Sulimani Governorate, named Tabin, Sarchinar, and Bestansur. Yousuf and Abullah (2011) explored for the concentration radiation Uranium (U) in different Sulimani governorate locations, including deep well, and spring. The authors targeted about thirty-eight deep wells and springs (Fig.2). H. S. Ahmad and Mustafa (2008) studied nitrate pollution in groundwater by using two water samples from karizes and sixty-eight water well samples. Kareem et al. (2015) and Kareem et al. (2018) took water samples from twelve wells around dumpsites and Sarchnar spring to investigate the environmental aspects of groundwater quality in the Tanjero region of the Sulaimani City, and They found the water of the area is not safe for domestic uses (Table 2 and Fig.2).

Outside of Sulimani City, Halabja, Kifri, Ganjo (2014) investigated Halabja groundwater

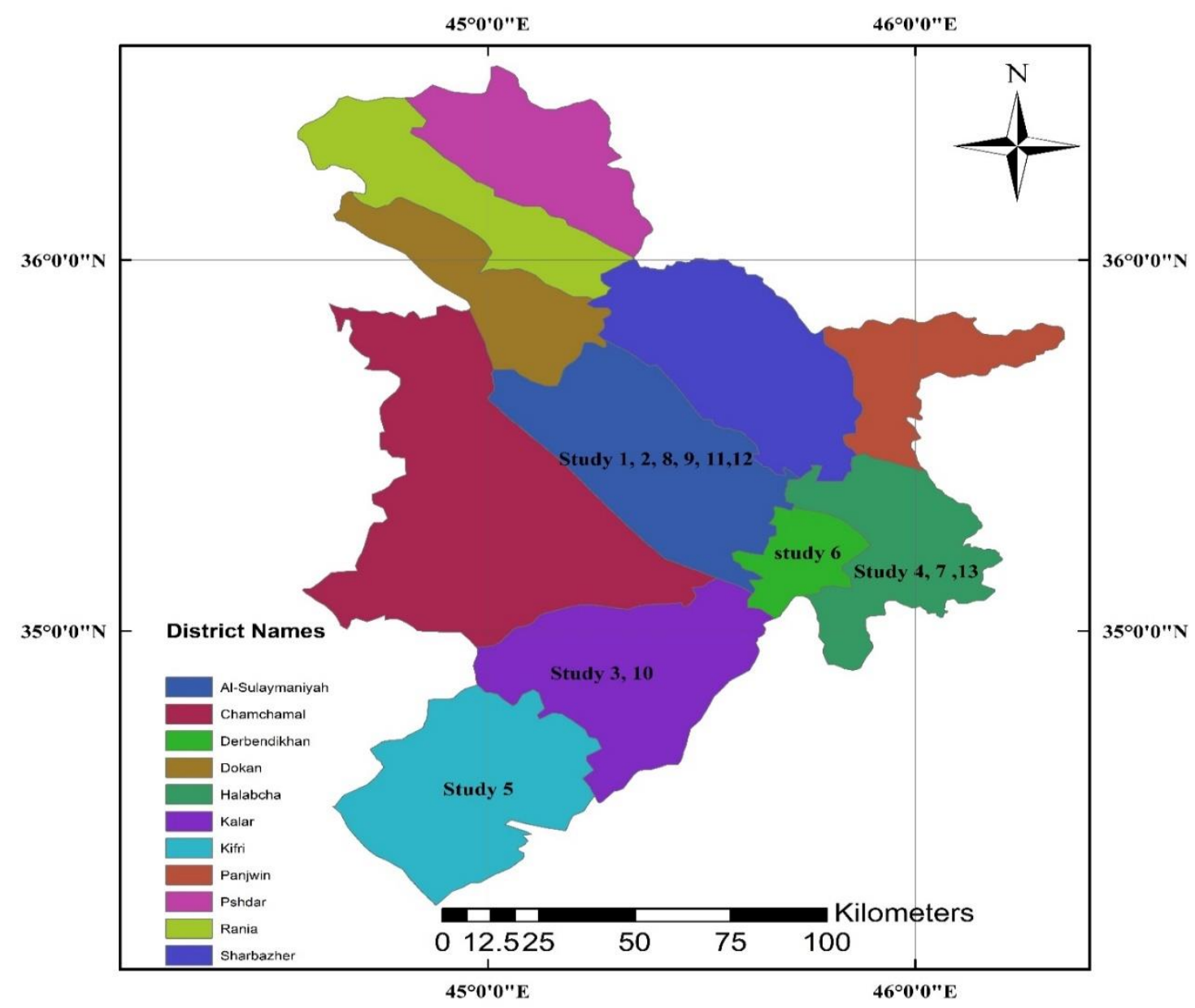

Fig. (2): Sulimani and Halabja Provinces

Kalar, and Darbandikhan districts are chosen for by collecting samples from five different groundwater quality research. Barzinji and locations in Halabja, water obtained from

dara.muhammad@koyauniversity.org,dara.hawez@gmail.com; Nashwan.shawkat@uod.ac: shuokr.aziz@su.edu.krd,shoker71@yahoo.com; juan.sabah@yahoo.com;

shwana.manguri@uor.edu.krd ${ }^{1}$ Corresponding author Department of Civil Engineering, Faculty of Engineering, Koya University Koya KOY45, Kurdistan Region - F.R. Iraq 
artesian wells drilled wells and karizes, they found water has good quality by compared to standards. Mohammed et al. (2018) worked on assessing the influence of long-term solid waste disposal on water and soil physicochemical characteristics in Halabja City. Also, the author found that waste disposal has a significant adverse impact on water quality. However, the mean values of many parameters analyzed fell below the WHO and EU standards for drinking water. Furthermore, Salih et al. (2015) collected water samples from 27 wells and examined for physic-chemical and biological properties. It found that the groundwater in the study region is suitable for drinking and other household purposes (Fig.2).

The quality of groundwater in Kalar City has been examined by Alshatteri and Murad (2015) and Al-Manmi (2007). Alshatteri and Murad (2015) took water samples from seven dug wells and seven drilled wells in Kalar City. Also, water samples from seventeen deep wells were taken by Al-Manmi (2007), and both of them concluded that most of the results were under the limits.

A. B. Ahmad (2014) conducted a study across seven villages near Darbandikhan District, including five springs and two wells, and according to the results, most of the parameters are in the limit (Table 2 and Fig.2). Also, Sarhat (2017) collected a water sample from fifteen deep wells in Kifri, and the author found in some wells recorded a $\mathrm{pH}$ value higher than 8.5 (Table 2 and Fig.2).

Table (2): Studies for Sulimani and Halabja Provinces

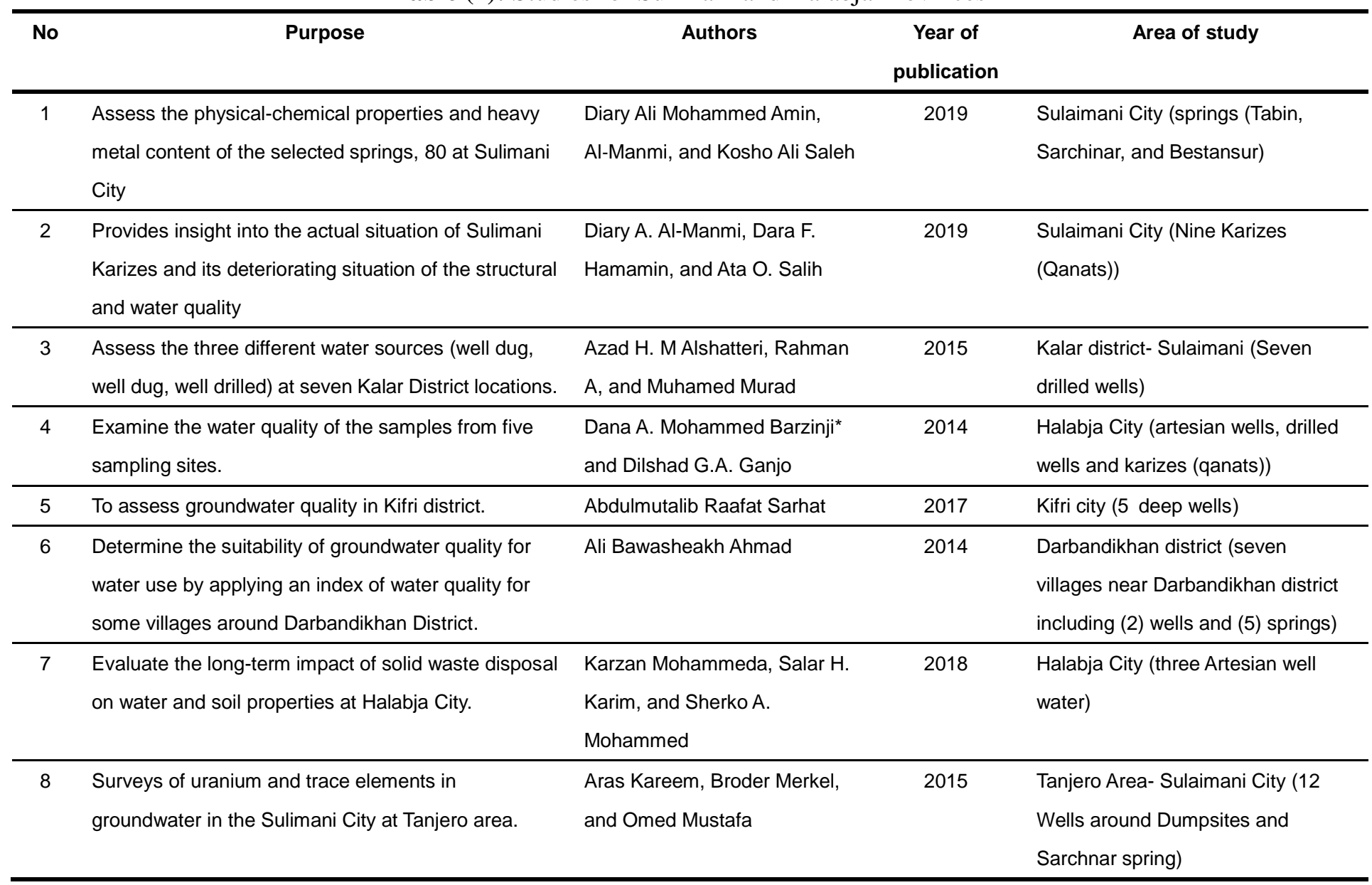

dara.muhammad@koyauniversity.org, dara.hawez@gmail.com; Nashwan.shawkat@uod.ac: shuokr.aziz@su.edu.krd,shoker71@yahoo.com; juan.sabah@yahoo.com; shwana.manguri@uor.edu.krd ${ }^{1}$ Corresponding author Department of Civil Engineering, Faculty of Engineering, Koya University Koya KOY45, Kurdistan Region - F.R. Iraq 


\begin{tabular}{|c|c|c|c|c|}
\hline 9 & $\begin{array}{l}\text { Geochemical and natural water quality analysis of the } \\
\text { area of Tanjero, in Sulimani City. }\end{array}$ & $\begin{array}{l}\text { Aras Kareem, Omed Mustafa, } \\
\text { and Broder Merkel }\end{array}$ & 2018 & $\begin{array}{l}\text { Tanjero area- Sulaimani City (12 } \\
\text { Wells around Dumpsites and } \\
\text { Sarchnar spring) }\end{array}$ \\
\hline 10 & Evaluation of groundwater quality at Kalar District. & Diary A. Al-Manmi & 2007 & $\begin{array}{l}\text { Kalar district - Sulaimani (Seventeen } \\
\text { Wells Dry Season and Seventeen } \\
\text { Wells Wet Season) }\end{array}$ \\
\hline 11 & $\begin{array}{l}\text { Assessment of uranium and radon concentrations in } \\
\text { bodies of water Sulimani province. }\end{array}$ & $\begin{array}{l}\text { Rasheed M. Yousuf, and } \\
\text { Kamal O. Abdullah }\end{array}$ & 2011 & $\begin{array}{l}\text { Sulaimani city (19 wells, } 7 \text { karizes } \\
\text { (qanats) and } 12 \text { springs) }\end{array}$ \\
\hline 12 & Study Nitrate pollution of Sulimani city's groundwater. & $\begin{array}{l}\text { Omed M. Mustafa and Hiwa S. } \\
\text { Ahmad }\end{array}$ & 2008 & $\begin{array}{l}\text { Sulaimani city ( } 68 \text { wells (domestic } \\
\text { and public) and } 2 \text { "Karez") }\end{array}$ \\
\hline 13 & $\begin{array}{l}\text { Measure the physic-chemical and biological } \\
\text { character of the different sources of drinking water in } \\
\text { Halabja District. }\end{array}$ & $\begin{array}{l}\text { Faisal A. Salih, Attallah O. } \\
\text { Kasem, Tareq H. Abdullah, } \\
\text { Nasih F. Othman, and } \\
\text { Muhammed B. }\end{array}$ & 2015 & Halabja City (27 municipality wells) \\
\hline
\end{tabular}

\subsubsection{Duhok Province,}

In Duhok Province, five research conducted on the quality of groundwater, theses article be listed in the table 3 .

Semeel, Akre, Shekhan, and Amedy are four districts of the Duhok government. The groundwater is the main water source for them. Al-Mezori and Hawrami (2011) noticed that water in some areas continued the high amount of fecal bacteria through testing the water quality of wells and springs in these districts. Hawrami and Mezuri (2014) looked for heavy metals in groundwater in these areas; also, they found water in Semeel, Akre, and Shekhan is safe for human consumption.

Zakho City is another district around Duhok city, Fig.3. Groundwater in eighteen villages around Zakho city was investigated by Umer et al. (2020). The authors collected the water samples and analyzed them for each month of the years 2018. Also, it was concluded the seasonal variation has no effects on all drinking water quality and water in most of the villages have high hardness concentration.

Ameen (2019) studied the Barwari Bala area groundwater and targeted the springs in ten villages within the Barwari Bala area. (Fig.3). The researcher looked for major physicochemical characteristics in the water of the springs (Table 3). And author stated that the current physicochemical parameters concentrations have no noticeable negative impacts on human health.

Umer et al. (2020) were assessed the groundwater for Kwashe industrial state located at around $20 \mathrm{~km}$ west of Duhok city (Fig.3). Though testing ten artesian wells, the researcher found contamination in water due to the high nitrate, sulfate, and chloride levels.

dara.muhammad@koyauniversity.org,dara.hawez@gmail.com; Nashwan.shawkat@uod.ac: shuokr.aziz@su.edu.krd,shoker71@yahoo.com; juan.sabah@yahoo.com; 


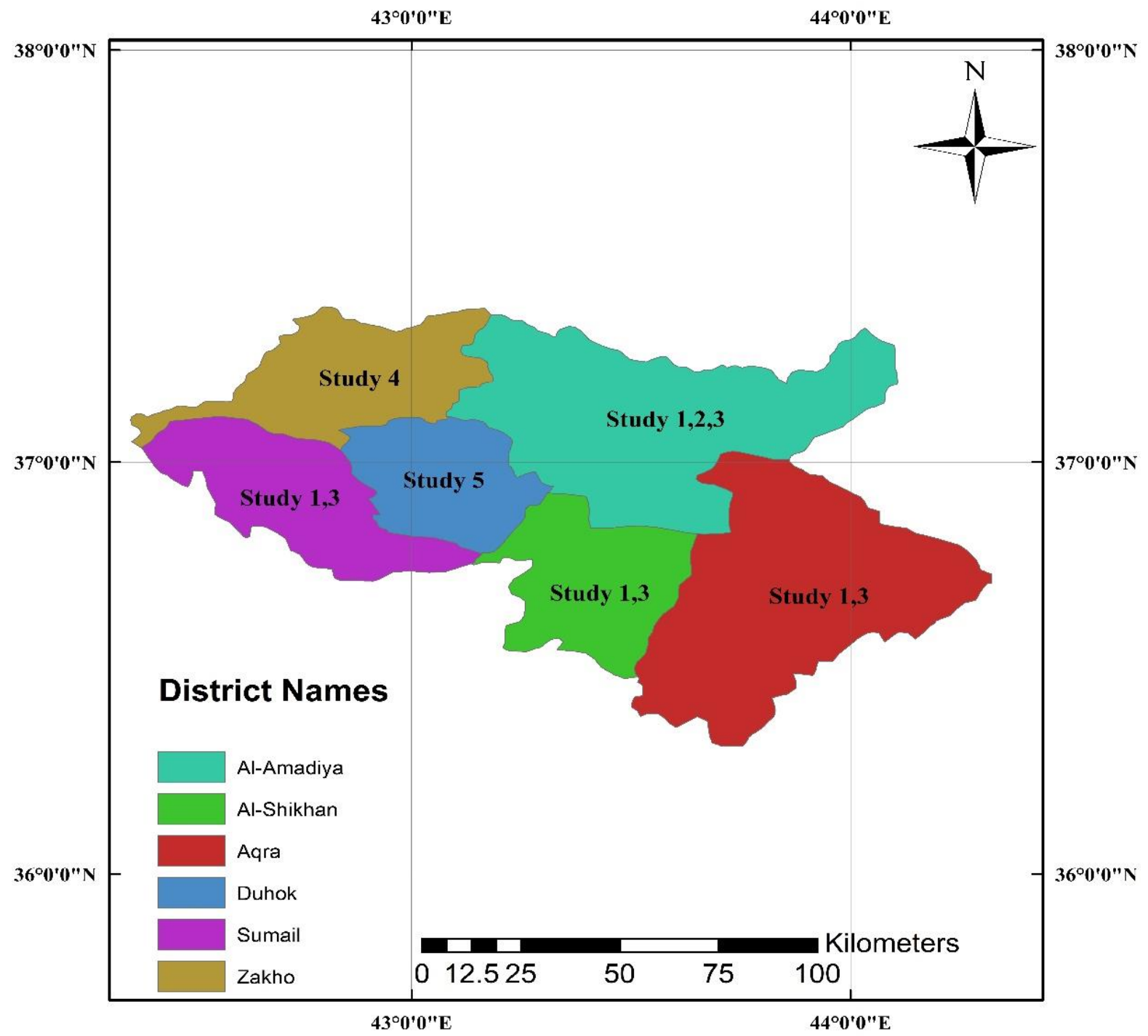

Fig. (3): Duhok Province

Table (3): Studies for Duhok Province

\begin{tabular}{|c|c|c|c|c|}
\hline No & Purpose & Authors & $\begin{array}{c}\text { Year of } \\
\text { publication }\end{array}$ & Area of study \\
\hline 1 & $\begin{array}{l}\text { Investigate drinking water bacterial contamination in the } \\
\text { province of Duhok and evaluate the efficiency of water } \\
\text { treatment plants }\end{array}$ & $\begin{array}{l}\text { Hassan Amin Al-Mezori } \\
\text { and Karzan A. M. } \\
\text { Hawrami }\end{array}$ & 2011 & Semeel, Akre, Shekhan, and Amedy \\
\hline 2 & $\begin{array}{l}\text { Bala Barwari Villages Springwater Quality Assessment Us } \\
\text { ig Water Quality Index }\end{array}$ & Hajar Ameen Ameen & 2019 & $\begin{array}{l}\text { Barwari Bala, Duhok (10 different } \\
\text { springs at two different sampling } \\
\text { periods) }\end{array}$ \\
\hline 3 & $\begin{array}{l}\text { Assess the levels of arsenic and other heavy metals in } \\
\text { pre-treated and post-treated water for projects in the } \\
\text { Duhok Province }\end{array}$ & $\begin{array}{l}\text { Karzan. Hawrami, and } \\
\text { Hassan. Mezuri }\end{array}$ & 2014 & $\begin{array}{l}\text { Duhok Province (Semeel, Shekhan } \\
\text { Akre and Amedy) }\end{array}$ \\
\hline
\end{tabular}

dara.muhammad@koyauniversity.org,dara.hawez@gmail.com; Nashwan.shawkat@uod.ac: shuokr.aziz@su.edu.krd,shoker71@yahoo.com; juan.sabah@yahoo.com;

shwana.manguri@uor.edu.krd ${ }^{1}$ Corresponding author Department of Civil Engineering, Faculty of

Engineering, Koya University Koya KOY45, Kurdistan Region - F.R. Iraq 


\begin{tabular}{cllll}
\hline 4 & Comparison of seasonal changes in certain chemical & Mustafa Ismail Umer, & 2020 & Villages (18 villages) around Zakho \\
& quality indicators in villages surrounding Zakho District. & Najlaa Mohammad Ali & District \\
& & Qaseem, Musher \\
& & Rashed and Ahmed Al- & \\
& Barwary & \\
\hline 5 & Assess contamination of groundwater caused by industrial & Mustafa I Umer, Payman & 2018 & Heavy Metals and Anions in \\
& contamination Effluents, and landfill leaching in Kwashe & A Abduljabar and Newar & Kwashe Industrial Area, Duhok City \\
& Industrial Area & A M Hamid2 & \\
\hline
\end{tabular}

\subsection{Data Collection and Analysis}

The thirty papers were reviewed and evaluated. The studies divide into three tables (1,2 and 3) according to the location and province. Also, the study areas shown in figures $(1,2$, and 3$)$. These tables and data were made with considering the location of study areas and the parameters which tested. For the same Province the papers which studied similar parameters inserted into the same table. Table 4 to 11 .

\subsection{Period of sampling}

Water samples were collected base on the purpose of the study. Most of the research samples were taken monthly throughout one year to cover the dry and wet season of the year such as study number (1), (2), (3),(4), (6), (7), and (12) in Erbil province, Similarly, in Sulimani study number (1), (4),(6),(12), and study number (1), (2), (3), and (4) in were conducted base on annual monitoring in Duhok Province. In contrast, the rest of the works were done on one time or some months in a year.

\subsection{Locations}

From the list of reviewed studies, a number of them focused on groundwater quality in center cities of Erbil and Sulimani, and Duhok, for example, studies number (3), (4), (5), (9), and (12) in Erbil city. For Sulimani City, only two studies tested underground water (2) and (12). In Duhok city, not a study has been reviewed related to groundwater inside Duhok city and that gap needs to be filled. In Halabja
City, Articles (4), (7), and (13) observed the groundwater.

In the Kurdistan Region, inside and around the cities, the industrial area has been grown rapidly in recent years. The environmental impact study through groundwater, these areas have considered by scholars. In Erbil Province, Kawergosk oil refinery is one of Kurdistan Region-Iraq 's biggest refineries. It placed in district Khabat. The impact of Kawergosk wastewater refinery (KRWW) on the enclosed water sources was conducted to investigate the properties of groundwater, KRWW, and GZR. This presented in paper number (1). Tanjero area is the industrial zone in Sulimani Provence. For the last decade, this industrial district expanded by increasing the number of factories for industrial products (Kareem et al., 2015). The groundwater was investigated by study number (8) and (9) and moreover, research number (5) examined the Kwashe Industrial Area groundwater in Duhok province.

In considering environmental impact and risk assessment of the dumpsite of solid waste, several researchers were conducted studies. The dumping sites in Erbil City and Halabja City were evaluated by investigated the groundwater. In Erbil City, study number (2), (10), and (11) were done evaluate the consequences of disposing of municipal solid waste and leachate on groundwater. Also, paper No. (7) examined the underground around dumpsite in Halabja city to assess impact of long-term solid waste

dara.muhammad@koyauniversity.org,dara.hawez@gmail.com; Nashwan.shawkat@uod.ac: shuokr.aziz@su.edu.krd,shoker71@yahoo.com; juan.sabah@yahoo.com; shwana.manguri@uor.edu.krd ${ }^{1}$ Corresponding author Department of Civil Engineering, Faculty of Engineering, Koya University Koya KOY45, Kurdistan Region - F.R. Iraq 
disposal on soil and water physicochemical characteristics.

Other researchers assessed groundwater quality in districts, towns and villages. For Erbil Province, article No. (6) contacted research on groundwater in Soran district. Also, Hammam Jalli as Thermal Spring is considered by article number (7). In Sulimani Province, Kalar city water is examined and analyzed by studies (3) and (10). likewise, Kifri city underground water checked by the research (5). Springs and wells water in Seven villages near Darbandikhan district were checked by study (6).

\subsection{Groundwater sources}

In the Kurdistan Region, groundwater mainly extorted from well, and natural springs. However, Karez (Qanat) is another source of underground water, especially in Sulimani Province. According to the types of groundwater, the evaluated studies can be presented. In Erbil, mainly water of wells were tested such as article (1),(2),(3),(4),(5),(8),(10),(11), and (12), The study (6),(7), and (9) were focused on springs in Erbil Provence as well.

For Sulimani, the papers considered the broader range of groundwater sources. Article (11) studied wells, Springs, and karizes (qanats) in Sulimani City. Studies (4), and (12) examined wells and karizes (qanats). However, Some Other studies such as (6), (8), and (9) checked wells and springs. The rest of the studies in Sulimani targeted single type of groundwater for example, (1) considered three springs, (2) studied nine karizes (qanats). Also, references Nos. (3),(5),(7), and(10), investigated only wells. In Duhok, papers (1), and (3) were studies springs and wells in Semeel, Akre, Shekhn, and Amedy districts. Study (2) investigated ten springs in Barwari Bala, and research number (5) examined ten wells in Kwashe Industrial Area.

\section{6 water parameters}

Reviewed papers were conducted for different reasons. To achieve their aims, the authors tested groundwater for different parameters. Such parameters as physics-chemical like $\mathrm{pH}$, conductivity, turbidity, total hardness, and total alkalinity frequently examined by the majority of authors. Besides, anions and cation, for instance, chloride, nitrate, sulphate, Calcium, Magnesium, Sodium were analyzed by other papers. Some of these studies targeted heavy metals and radiation elements. Some other studies consider biological parameters such as Total Coliform (MPN) and faecal coliform.

\section{RESULTS AND DISCUSSIONS}

\subsection{Groundwater characteristics}

The results and data from reviewed research classified base on characteristics:

\subsection{1 pH Value}

$\mathrm{pH}$ is the most frequently examined parameter in water and soil investigation. It stands for the alkaline or acidic of a liquid and is ranked on a range of one to fourteen. Although $\mathrm{pH}$ does not affect human life, it is intimately linked with more chemical substances of water. (Narsimha \& Sudarshan, 2017).

The $\mathrm{pH}$ value measured parameter for almost all of the studies in Erbil province except study by Zangana et al. (2014) and Jadoon et al. (2015) .The outcomes of all tests showed that the highest pH Value is 8.9 in Zone two in Erbil city (Daham et al., 1998). The $\mathrm{pH}$ value of water in this area is out the range of standard for drinking water (6.5-8.5) (USEPA, 2018). Aziz and Fakhrey (2016) measured the high value of $\mathrm{pH}$ in Small Agulan, which 8.23 in January 2015. The rest of the results of $\mathrm{pH}$ were in range $(8.25$ to 6.8) which are acceptable for drinking purpose.

For Sulimani Province, the majority of tested was in the range of (6.5 to 8.5), Hoverer, Kareem et al. (2015) and Kareem et al. (2018) reported

dara.muhammad@koyauniversity.org,dara.hawez@gmail.com; Nashwan.shawkat@uod.ac: shuokr.aziz@su.edu.krd,shoker71@yahoo.com; juan.sabah@yahoo.com; shwana.manguri@uor.edu.krd ${ }^{1}$ Corresponding author Department of Civil Engineering, Faculty of Engineering, Koya University Koya KOY45, Kurdistan Region - F.R. Iraq 
the highest $\mathrm{pH}$ value in well No. 8 which is about 8.88 in Tanjero area (Table 8 ).

Also, in Duhok Area, $\mathrm{pH}$ value is in the range of WHO and USEPA; therefore, it has not a health concern. Despite that, Asaf Village near
Zakho District recorded high $\mathrm{pH}$-value. the $\mathrm{pH}$ range is (8.0 to 8.5$)$, Fig. 4. This may occur due to widely from carbonate rocks such as dolostone and limestone. (Umer et al., 2020).

Table (4): Characteristics of Groundwater in Erbil Province - Part I

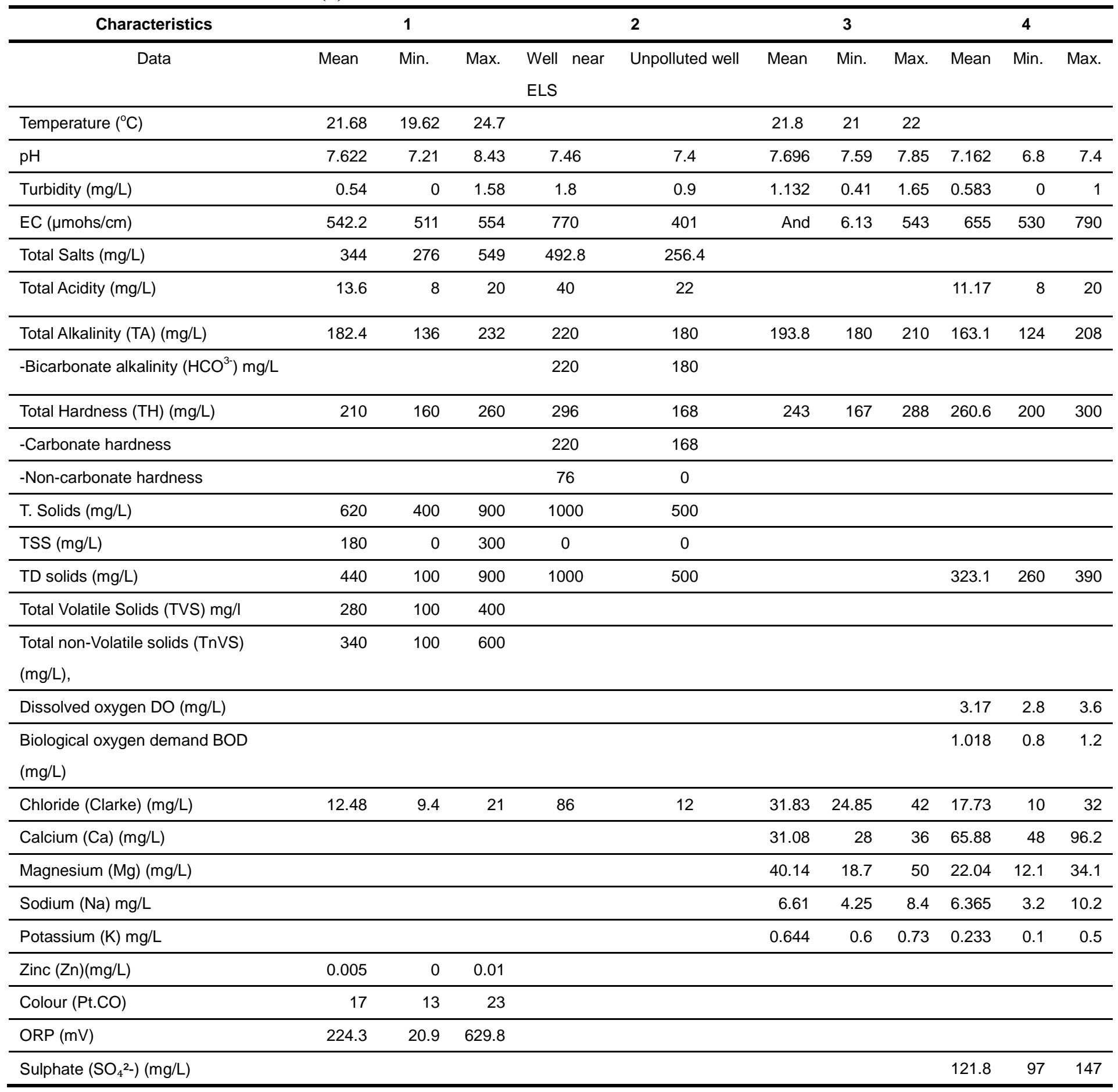

dara.muhammad@koyauniversity.org,dara.hawez@gmail.com; Nashwan.shawkat@uod.ac: shuokr.aziz@su.edu.krd,shoker71@yahoo.com; juan.sabah@yahoo.com;

shwana.manguri@uor.edu.krd ${ }^{1}$ Corresponding author Department of Civil Engineering, Faculty of Engineering, Koya University Koya KOY45, Kurdistan Region - F.R. Iraq 


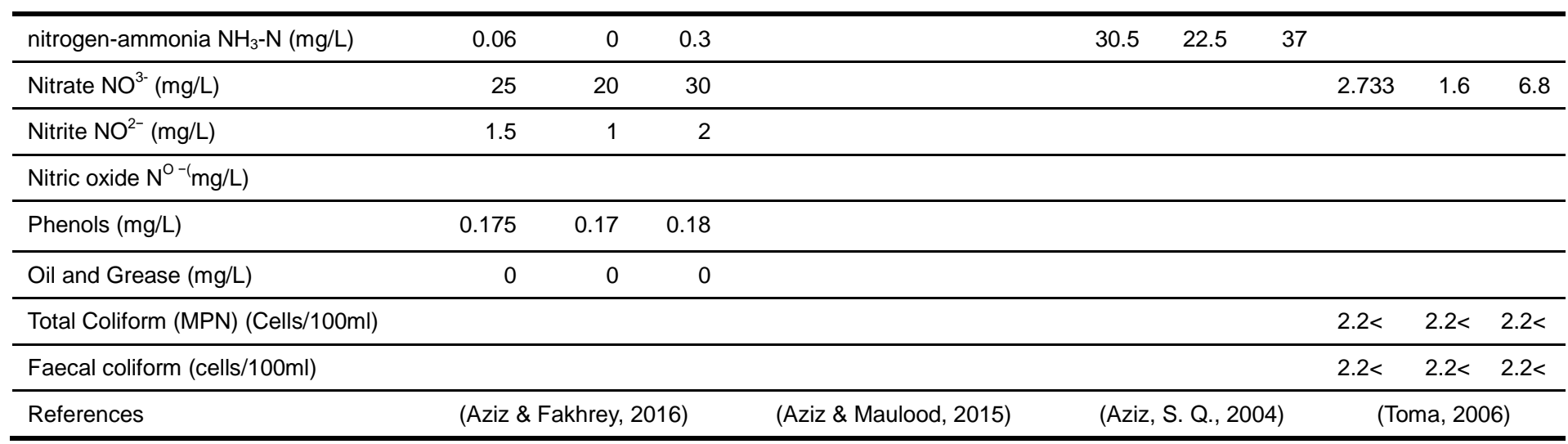

Table (5): Characteristics of Groundwater in Erbil Province - Part II

\begin{tabular}{|c|c|c|c|c|c|c|c|c|c|}
\hline \multirow{3}{*}{$\begin{array}{l}\text { Characteristics } \\
\text { Data }\end{array}$} & \multirow[b]{3}{*}{ Mean } & \multirow{3}{*}{$\begin{array}{c}5 \\
\text { Min }\end{array}$} & \multirow[b]{3}{*}{ Max } & \multicolumn{6}{|c|}{6} \\
\hline & & & & \multicolumn{3}{|c|}{ twenty Wells } & \multicolumn{3}{|c|}{ twenty Springs } \\
\hline & & & & Mean & Min. & Max. & Mean & Min. & Max. \\
\hline Temperature $\left({ }^{\circ} \mathrm{C}\right)$ & & & & 19.0 & 18.7 & 19.2 & 15.0 & 14.6 & 15.2 \\
\hline $\mathrm{pH}$ & 7.8 & 7.2 & 8.9 & 7.2 & 7.1 & 7.2 & 7.4 & 7.3 & 7.5 \\
\hline Turbidity (mg/L) & 3.7 & 1.5 & 7.8 & 3.6 & 3.2 & 3.8 & 3.2 & 2.8 & 3.5 \\
\hline $\mathrm{EC}(\mu \mathrm{mohs} / \mathrm{cm})$ & 431.7 & 36.0 & 800.0 & 998.6 & 961.5 & 1113.9 & 538.3 & 527.9 & 564.3 \\
\hline Total Alkalinity (TA) (mg/L) & 282.4 & 220.0 & 410.0 & 378.0 & 369.9 & 395.6 & 254.0 & 246.9 & 271.5 \\
\hline Total Hardness (TH) (mg/L) & 331.5 & 228.0 & 544.0 & 487.0 & 473.6 & 496.4 & 393.0 & 369.1 & 402.3 \\
\hline TD solids (mg/L) & 246.5 & 26.0 & 640.0 & 639.2 & 613.8 & 712.5 & 345.3 & 336.8 & 360.7 \\
\hline Dissolved oxygen DO (mg/L) & & & 0.0 & 6.6 & 6.5 & 6.8 & 7.0 & 6.7 & 7.3 \\
\hline Chloride (Cl) (mg/L) & & & 0.0 & 95.8 & 79.8 & 102.5 & 38.1 & 31.0 & 41.1 \\
\hline Calcium (Ca) (mg/L) & 85.6 & 56.0 & 280.0 & 403.0 & 290.9 & 426.6 & 305.0 & 221.6 & 334.2 \\
\hline Magnesium (Mg) (mg/L) & 39.1 & 11.5 & 121.0 & 84.0 & 63.2 & 182.0 & 89.0 & 61.9 & 155.0 \\
\hline Chromium (Cr) (mg/L) & 51.1 & 19.0 & 196.0 & & & & & & \\
\hline Iron (ferrum) (Fe) (mg/L) & 0.3 & 0.1 & 0.8 & & & & & & \\
\hline Sulphate $\left(\mathrm{SO}_{4}{ }^{3-}\right)(\mathrm{mg} / \mathrm{L})$ & 38.6 & 5.0 & 144.0 & 66.0 & 61.4 & 70.2 & 32.6 & 30.0 & 45.3 \\
\hline Nitrate $\mathrm{NO}^{3-}$ (mg/L) & & & 0.0 & 3.3 & 3.0 & 3.6 & 2.3 & 2.0 & 2.6 \\
\hline $\begin{array}{l}\text { Total Coliform (MPN) } \\
\text { (Cells/100ml) }\end{array}$ & 1.9 & 0.0 & 5.0 & & & & & & \\
\hline
\end{tabular}

References $\quad$ (Daham et al., 1998) (Al-Barwary et al., 2018)

\subsubsection{Turbidity}

Turbidity relates to water pellucidity or the level of cloudiness. Water with Extreme turbidity proved an excess of contamination because of coal dust, silt, microorganisms, ash, sawdust, plant fibers, and organic particles (organisms or precipitant (e.g. Iron and manganese) (WHO, 2017). Most turbidity in the surface water is due

dara.muhammad@koyauniversity.org,dara.hawez@gmail.com; Nashwan.shawkat@uod.ac: shuokr.aziz@su.edu.krd,shoker71@yahoo.com; juan.sabah@yahoo.com;

shwana.manguri@uor.edu.krd ${ }^{1}$ Corresponding author Department of Civil Engineering, Faculty of 
to plankton or soil particles associated with mining, logging, or drilling operations (Association et al., 2017). However, blasting and construction activities make fractured bedrock of aquifers. This mainly causes Groundwater turbidity. Instability of some inorganic materials such as manganese and iron may also lead to turbidity in groundwater (Akhtar et al., 2014).

According to the USEPA standard, the drinking water should have Lower than 5 NTU. Most water samples contained in the studied region is suitable for drinking and household use. However, only two areas of the water samples examined had turbidity nearby to and above 5 NTU. The water in Erbil city wells have outranged in turbidity in zone one and zone two (Daham et al., 1998) ,Table 5. Moreover, groundwater in Miradee village near Darbandikhan District in Sulimani Province has 4.94 NTU of turbidity which just under the limit of USEPA (A. B. Ahmad, 2014) (Table 8).

\subsubsection{Total Solids, Total Dissolved Solids and Total Suspended Solids}

Total solids can be classified into, suspended, dissolved, and settleable solids in water. In surface and groundwater, dissolved solids formed from calcium, sulfur, nitrate, iron, chlorides, phosphorus, and other ions particles move through a filter with holes of around two microns in size. Similarly, TDS is the inorganic salts and small amounts of organic matter present in water solution. In contrast, suspended solids produced from clay and silt particles, algae, plankton, fine organic debris, and other particulate matter. These are particles that will be caught by a 2-micron filter. (WHO, 2003). The USEPA (2018) has an approved limit of 500 $\mathrm{mg} / \mathrm{L}$ for (TDS) in secondary Drinking Water Regulations. Also, WHO (2017) ) stated that water with a TDS of under $1000 \mathrm{mg} / \mathrm{L}$ is generally reasonable. Drinking water at TDS levels greater than $1000 \mathrm{mg} / \mathrm{L}$ becomes significantly unpalatable. Because the appearance at Such range of TDS in water can affect your taste (Bruvold \& Ongerth, 1969) .

In Erbil, Aziz and Fakhrey (2016) and Aziz and Maulood (2015) tasted wells for total solids, total suspended Solids, and TDS. The results showed that total suspended solids have the range (180 to 300) (Aziz \& Fakhrey, 2016). The maximum concentration for TDS in both studies is 900 and $1000 \mathrm{mg} / \mathrm{L}$. TDS has the 900 and $1000 \mathrm{mg} / \mathrm{L}$ maximum concentration which is in range of the WHO limits (Aziz \& Fakhrey, 2016; Aziz \& Maulood, 2015) (Table 4).

For Sulimani, seven papers examined the groundwater for total solids and TDS (Tables 7, 8, and 9). Among these studies, only Sarhat (2017) and Salih et al. (2015) reported a high value of TDS $839 \mathrm{mg} / \mathrm{L}$ and $705.2 \mathrm{mg} / \mathrm{L}$ (Tables 7, and 9).

For Duhok province, from two papers which stated the values of total dissolved solid all value were under 600 mg/L (Ameen, 2019; Umer et al., 2020).

\subsubsection{Electrical conductivity}

Electric conductivity is the amount of total substitution dissolved in water (Yİlmaz \& Koç, 2014). Water salinity and TDS can be estimated based on electrical conductivity. However, it is a useful indicator of TDS and total salinity; it does not provide any knowledge regarding the ionic composition inside the water sample (Hem, 1985).

Tables 4 to 11 show electrical conductivity values of the groundwater in the Kurdistan Region. Recorded values ranged from 0.326-1777 $\mu \mathrm{mohs} / \mathrm{cm}$. The overall electrical conductivity value is more than $400(\mu \mathrm{mohs} / \mathrm{cm})$ in most of the studies.

\subsubsection{Total Alkalinity}

Alkalinity is the potential buffering of a body of water. It regulates water 's capacity to neutralize bases and acids, thus, keeping a

dara.muhammad@koyauniversity.org,dara.hawez@gmail.com; Nashwan.shawkat@uod.ac: shuokr.aziz@su.edu.krd,shoker71@yahoo.com; juan.sabah@yahoo.com; shwana.manguri@uor.edu.krd ${ }^{1}$ Corresponding author Department of Civil Engineering, Faculty of Engineering, Koya University Koya KOY45, Kurdistan Region - F.R. Iraq 
reasonably constant $\mathrm{pH}$. Without alkalinity potential to neural the water, if acid runs to a water surface, it would directly alter its $\mathrm{pH}$ (Akhtar et al., 2014). Soil s and rocks are the main sources of alkalinity in water. Geological formation with height quantities of calcium carbonate (limestone, $\mathrm{CaCO} 3$ ) tends to increase concentration Alkalinity in water. Furthermore, some industry and plant wastewater may become the source of alkalinity in water. In low alkalinity water, $\mathrm{pH}$ will decrease, and water tends to be acidic. This acidic water can damage household plumbing through the corrosive action of the water. This may lead to leach out copper and lead from the pipe system. Additionally, another side effect of low alkalinity is eye irritation. In Contrast, the high concentration of alkalinity can cause dry skin, and scaling in puling fixtures and pipes (Saskatchewan, 2010) . A proper alkaline balance in groundwater is vital. But Alkalinity levels are generally observed in conjunction with $\mathrm{pH}$ levels to get a lot of idea of water condition.

The WHO and USEPA standards don't cover alkalinity. Canada drinking water standard supports range of alkalinity is $80-120 \mathrm{mg} / \mathrm{L}$ for level for swimming pool water and in India 200 $\mathrm{mg} / \mathrm{L}$ is deemed the satisfactory top limit (Standards, 2012). The alkalinity of the investigated samples range from a minimum of $19.8 \mathrm{mg} / \mathrm{L}$ to a maximum of $410 \mathrm{mg} / \mathrm{L}$ (Tables 4 to 11 ), and the highest levels occur groundwater at zone one in Erbil City (Daham et al., 1998).

Table (6): Characteristics of Groundwater in Erbil Province - Part III

\begin{tabular}{|c|c|c|c|c|c|c|c|c|c|c|c|c|c|c|c|c|}
\hline \multirow{3}{*}{$\begin{array}{l}\text { Characteristics } \\
\text { Data }\end{array}$} & \multirow[t]{2}{*}{7} & \multicolumn{3}{|c|}{8} & \multicolumn{6}{|c|}{9} & \multirow{2}{*}{\multicolumn{3}{|c|}{10 and 11}} & \multirow{2}{*}{\multicolumn{3}{|c|}{12}} \\
\hline & & & & & \multicolumn{3}{|c|}{ Thirty wells } & \multicolumn{3}{|c|}{ three springs } & & & & & & \\
\hline & & Mea & Min & Max & Mean & Min & Max & Mean & Min & Max & \multirow{2}{*}{$\begin{array}{l}\text { Mea } \\
\mathrm{n}\end{array}$} & \multirow[t]{2}{*}{ Min } & \multirow{2}{*}{$\begin{array}{l}\text { Ma } \\
x\end{array}$} & \multirow{2}{*}{$\begin{array}{l}\text { Mea } \\
\mathrm{n}\end{array}$} & \multirow[t]{2}{*}{ Min } & \multirow[t]{2}{*}{ Max } \\
\hline & & $\mathrm{n}$ & & & & & & & & & & & & & & \\
\hline \multirow[t]{2}{*}{ Temperature $\left({ }^{\circ} \mathrm{C}\right)$} & & & & & 20.70 & 16.00 & 23.00 & 16.50 & 14.0 & 21.0 & & & & & & \\
\hline & & & & & & & & & 0 & 0 & & & & & & \\
\hline \multirow[t]{2}{*}{$\mathrm{pH}$} & & & & & 7.73 & 7.33 & 8.25 & 7.70 & 7.53 & 7.81 & 7.36 & 7.1 & 7.6 & 7.39 & 7.1 & 7.7 \\
\hline & & & & & & & & & & & 7 & & & 6 & & \\
\hline \multirow[t]{2}{*}{ Turbidity (mg/L) } & & & & & & & & & & & 0.46 & 0.4 & 0.6 & & & \\
\hline & & & & & & & & & & & 7 & & & & & \\
\hline \multirow[t]{2}{*}{$\mathrm{EC}(\mu \mathrm{mohs} / \mathrm{cm})$} & & & & & 840.7 & 265 & 1940 & 954.3 & 453 & 177 & 760. & 516 & 106 & 427. & 266 & 622 \\
\hline & & & & & & & & & & 7 & 3 & & & 3 & & \\
\hline Total Alkalinity & & & & & & & & & & & & & & 164. & 110 & 240 \\
\hline (mg/L) & & & & & & & & & & & & & & 1 & & \\
\hline -Bicarbonate & & & & & 161.3 & 49.1 & 210.9 & 159.3 & 127 & 178 & 29.3 & 20 & 37 & & & \\
\hline alkalinity $\left(\mathrm{HCO}^{3-}\right)$ & & & & & & & & & & & 3 & & & & & \\
\hline \multicolumn{17}{|l|}{$\mathrm{mg} / \mathrm{L}$} \\
\hline Total Hardness & & & & & & & & & & & 286 & 232 & 340 & 237. & 180 & 298 \\
\hline (mg/L) & & & & & & & & & & & & & & 6 & & \\
\hline \multirow[t]{2}{*}{ TD solids (mg/L) } & & & & & 538 & 169.6 & 1241 & 572.7 & 272 & 106 & 486. & 330 & 680 & 255. & 170. & 363. \\
\hline & & & & & & & & & & 6 & 7 & & & 9 & 2 & 7 \\
\hline Chloride $(\mathrm{Cl})(\mathrm{mg} / \mathrm{L})$ & 46.7 & 6.41 & 2.16 & 23 & 40.26 & 8.40 & 123.6 & 27.33 & 13.0 & 53.0 & 20.3 & 11 & 29 & & & \\
\hline
\end{tabular}

dara.muhammad@koyauniversity.org,dara.hawez@gmail.com; Nashwan.shawkat@uod.ac: shuokr.aziz@su.edu.krd,shoker71@yahoo.com; juan.sabah@yahoo.com; shwana.manguri@uor.edu.krd ${ }^{1}$ Corresponding author Department of Civil Engineering, Faculty of 


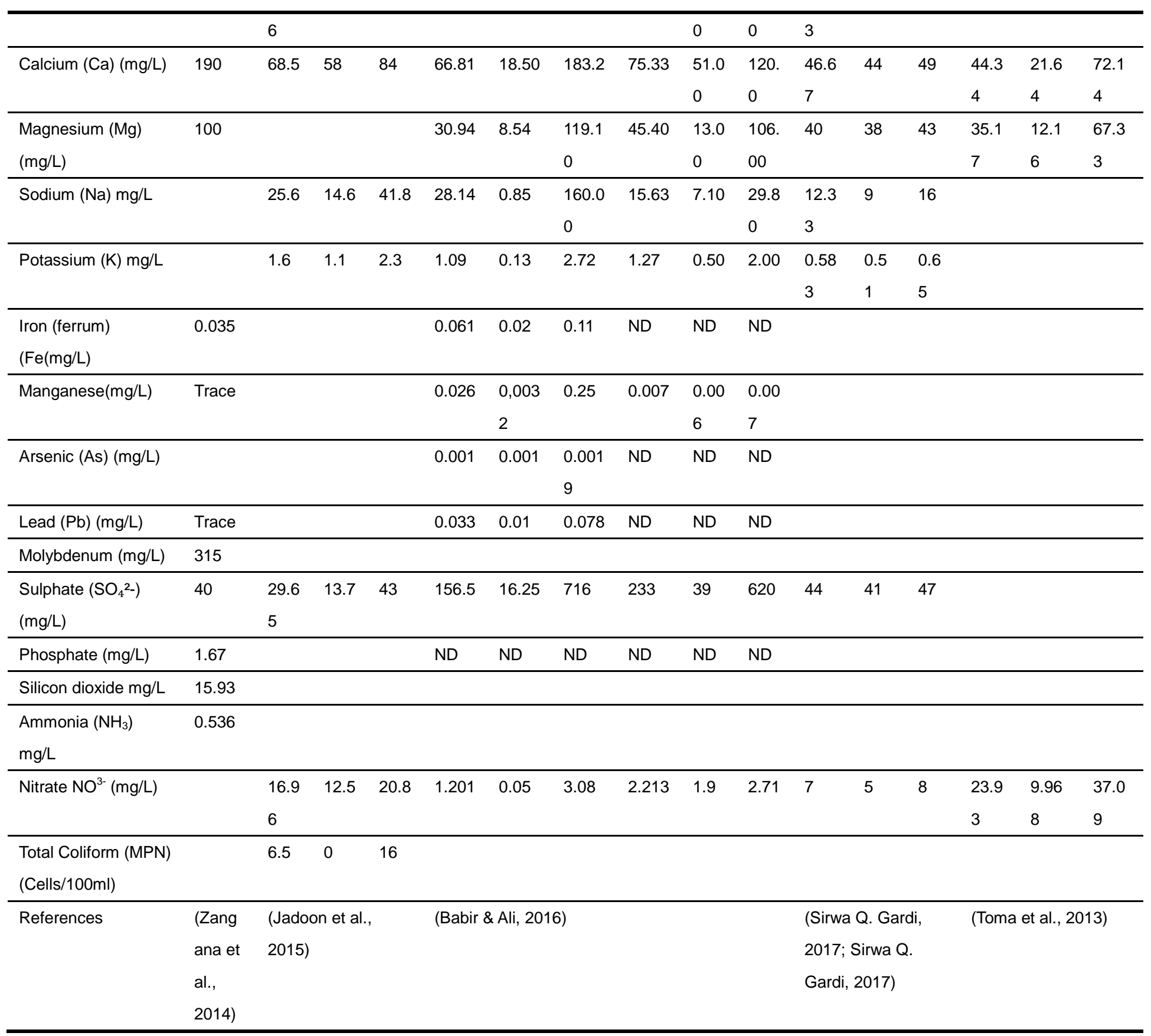

\subsubsection{Total Hardness}

Calcium and magnesium are two elements that regularly in charge of hardness in water. There are two main types of The Total Hardness (TH) in water: temporarily and permanent hardness. The combination of these two constitutes TH. Water boiling can remove the temporary hardness, but permanent hardness needs further complex processing for treatment. The presence of a high concentration of calcium and magnesium can lead to alterations in the chemical of water. Available of the high amount of hardness executes soap insoluble. The water with a high concentration of hardness can create scum and curd on boiling can cause discoloration of fabrics, and can make medical issues such as heart diseases (W. Smith \& Crombie, 1987).

For drinking purposes, the highest allowable limit of total hardness is $500 \mathrm{mg} / \mathrm{L}$, and the most

dara.muhammad@koyauniversity.org,dara.hawez@gmail.com; Nashwan.shawkat@uod.ac: shuokr.aziz@su.edu.krd,shoker71@yahoo.com; juan.sabah@yahoo.com;

shwana.manguri@uor.edu.krd ${ }^{1}$ Corresponding author Department of Civil Engineering, Faculty of Engineering, Koya University Koya KOY45, Kurdistan Region - F.R. Iraq 
desirable limit is $100 \mathrm{mg} / \mathrm{L}$ according to WHO standard. More than $300 \mathrm{mg} / \mathrm{L}$ of total hardness in groundwater is recognized as quite hard and unqualified for most applications (Sawyer, 1967). For the most suitable range of hardness (as $\mathrm{CaCO}_{3}$ ) is 80 to $100 \mathrm{mg} / \mathrm{L}$ provides an adequate equilibrium between incrustation and corrosion (Canada et al., 2019).

All analyzed samples from the Kurdistan region have total hardness within the guided ranges of WHO, Tables 4 to 11. However, Daham et al. (1998) stated the highest TH in zone three in Erbil city.

\subsubsection{Chloride, Calcium and Magnesium}

The quality of groundwater is affected by the metals and minerals that react with the water in its slowly move into the soil deposit's rocks and sands. Several variables make a considerable change in groundwater quality. Groundwater regularly increases its mineral content as it moves into the holes and openings of fractures in rocks. This is why it is deeper; older waters can be very mineral (S. Smith \& Rau, 1982).

Chloride's primary source is (salt), and brines. Anthropogenic (human) chloride sources include fertilizer, salt from streets, human and animal waste, and industrial activities. These sources can elevate high chloride concentrations in shallow groundwater because chloride is moved quickly into the soil (Agency, 1999a).

According to WHO (2017)., the $250 \mathrm{mg} / \mathrm{L}$ or higher of Chloride concentrations would likely be detected by taste. But, not the value of a health guideline is recommended for chloride in portable water.

The reviewed studies reveal that chloride concentration is in range ( 0.6 to 123.6$) \mathrm{mg} / \mathrm{L}$ in groundwater in all three provinces. All the results are well below $250 \mathrm{mg} / \mathrm{L}$ (Tables 4 to 11).

Calcium is a quintessential element for living people that play a role in the permeability of cell walls and formation in teeth and bones .Prescribed daily intakes of the it have been set in most countries (Cotruvo \& Bartram, 2009).

Magnesium is a mineral of abundance in the human body. It is commonly found in dietary supplements, many foods, added to other foods and found in some medicines (Health, 2020). Magnesium is an integral part of the human body. It contributes to many parts of the boy, such as bone, DNA, RNA, and the antioxidant glutathione. It also involves the active transfer of calcium and potassium ions across the membrane of cells (Ross et al., 2012).

Both Calcium and Magnesium dissolved from all kinds of rocks and soils, mainly from gypsum, dolomite, and calcium limestone. Magnesium is available in great quantities in seawater. It makes most of the water's hardness and scale-forming. Water low in calcium and magnesium is preferred in the manufacture, tanning, electroplating and textiles factory. Magnesium and Calcium are the major causes of the formation of a scale in water heaters and pipes, boilers, and in the presence of soap to the objectionable curd. These mineral components have a significant impact on water value for household demand and industrial processes (S. Smith \& Rau, 1982).

There is no guideline for Calcium and Magnesium in USEPA and WHO. Also, Canadian Drinking Water Quality Stated that no evidence of unfavorable health effects from magnesium and calcium in drinking water. Therefore a guideline value is not required (Canada et al., 2019).

For the studies in groundwater in Kurdistan, the magnesium and calcium Concentration varied from (6.9 to 426$) \mathrm{mg} / \mathrm{L}$ and (0.05 to 182$)$ $\mathrm{mg} / \mathrm{L}$ respectively (Tables 4 to 11 ). This indicates hardness in some areas of the study.

dara.muhammad@koyauniversity.org,dara.hawez@gmail.com; Nashwan.shawkat@uod.ac: shuokr.aziz@su.edu.krd,shoker71@yahoo.com; juan.sabah@yahoo.com; shwana.manguri@uor.edu.krd ${ }^{1}$ Corresponding author Department of Civil Engineering, Faculty of Engineering, Koya University Koya KOY45, Kurdistan Region - F.R. Iraq 
Table (7): Characteristics of Groundwater in Sulimani and Halabja Provinces - Part I

\begin{tabular}{|c|c|c|c|c|c|c|c|c|c|c|c|c|c|c|c|}
\hline Characteristics & & 1 & & & 2 & & & 3 & & & 4 & & & 5 & \\
\hline Data & mean & Min. & Max. & mean & Min. & Max. & mean & Min. & Max. & mean & Min. & Max. & mean & Min. & Max. \\
\hline Temperature $\left({ }^{\circ} \mathrm{C}\right)$ & 18.7 & 16.95 & 20.35 & 20.32 & 19.3 & 21.6 & & & & & & & & & \\
\hline $\mathrm{pH}$ & 7.275 & 7.12 & 7.51 & 7.092 & 6.82 & 7.65 & 7.433 & 7.36 & 7.54 & & & & 8.207 & 7.6 & 8.8 \\
\hline Turbidity (mg/L) & & & & & & & 1.706 & 0.31 & 3.69 & & & & 1.285 & 0.6 & 2.1 \\
\hline EC $(\mu \mathrm{mohs} / \mathrm{cm})$ & 381.6 & 325 & 411 & 507.4 & 321 & 810 & 706.9 & 518 & 1122 & & & & 940.3 & 407 & 1311 \\
\hline Total Alkalinity (TA) (mg/L) & & & & & & & 166.4 & 156 & 174 & 22.58 & 19.8 & 24.36 & & & \\
\hline $\begin{array}{l}\text {-Bicarbonate alkalinity } \\
\left(\mathrm{HCO}^{3-}\right)(\mathrm{mg} / \mathrm{L})\end{array}$ & 229.6 & 200 & 244 & 159.6 & 103 & 229 & & & & & & & 194 & 135.3 & 236.9 \\
\hline $\begin{array}{l}\text { Total Hardness (TH) } \\
(\mathrm{mg} / \mathrm{L})\end{array}$ & & & & & & & 301.1 & 234 & 330 & 318.3 & 248.8 & 352.5 & 437.7 & 202 & 676 \\
\hline -Non-carbonate hardness & & & & & & & & & & 159.9 & 41.34 & 291.2 & & & \\
\hline TD solids (mg/L) & & & & 326.8 & 206 & 518.4 & 524.3 & 507 & 570 & & & & 571.6 & 260 & 839 \\
\hline $\begin{array}{l}\text { Dissolved oxygen DO } \\
(\mathrm{mg} / \mathrm{L})\end{array}$ & & & & & & & 6.714 & 3 & 11 & & & & & & \\
\hline Chloride $(\mathrm{Cl})(\mathrm{mg} / \mathrm{L})$ & 18.7 & 16.4 & 19.7 & 32.62 & 10 & 70 & 24.93 & 8 & 35.5 & 13.28 & 12.08 & 15.23 & 53.13 & 18 & 90 \\
\hline Calcium (Ca) (mg/L) & 95.51 & 94.05 & 98 & 56.32 & 33 & 100 & 93.86 & 87 & 99 & & & & 122.5 & 58 & 240 \\
\hline Magnesium $(\mathrm{Mg})(\mathrm{mg} / \mathrm{L})$ & 8.938 & 6.55 & 11 & 16.72 & 9 & 32 & 21.14 & 10 & 33 & & & & 35.86 & 11 & 80.1 \\
\hline Sodium (Na) mg/L & 4.885 & 4.04 & 5.5 & 9.089 & 2 & 20 & 50 & 37 & 69 & 2.124 & 1.59 & 2.83 & 45.76 & 5.63 & 69.76 \\
\hline Potassium (K) mg/L & 1.115 & 0.98 & 1.32 & 0.814 & 0.2 & 1.9 & 1.659 & 1.4 & 1.86 & 1.128 & 1.07 & 1.16 & 1.919 & 0.63 & 2.88 \\
\hline Zinc (Zn) ( $\mu g / L)$ & & & & 36.67 & n.d & 50 & & & & & & & & & \\
\hline Cadmium $(\mathrm{Cd})(\mathrm{mg} / \mathrm{L})$ & B.D. L & B.D. L & B.D. L & 0.002 & n.d & 0.002 & & & & & & & & & \\
\hline Chromium $(\mathrm{Cr})(\mu \mathrm{g} / \mathrm{L})$ & & & & 12 & n.d & 20 & & & & 2116 & 2050 & 2180 & & & \\
\hline Cobalt (Co) (mg/L) & & & & & & & & & & 2.142 & 2.09 & 2.25 & & & \\
\hline Copper $(\mathrm{Cu})(\mathrm{mg} / \mathrm{L})$ & 0.048 & 0.03 & 0.06 & 0.009 & n.d & 0.03 & & & & 0.944 & 0.92 & 0.96 & & & \\
\hline Nikel (Ni) ( $\mu \mathrm{g} / \mathrm{L})$ & B.D. L & B.D. L & B.D. L & 2.867 & n.d & 4 & & & & 398 & 290 & 670 & & & \\
\hline Lead $(\mathrm{Pb})(\mu \mathrm{g} / \mathrm{L})$ & B.D. L & B.D. L & B.D. L & 6 & n.d & 10 & & & & 304 & 230 & 400 & & & \\
\hline Molybdenum (Mo) (mg/L) & & & & & & & & & & 0.208 & 0.15 & 0.27 & & & \\
\hline Sulphate $\left(\mathrm{SO}_{4}{ }^{2-}\right)(\mathrm{mg} / \mathrm{L})$ & 49.31 & 44 & 57.25 & 52.23 & 15 & 98 & 62.43 & 52 & 83 & 0.666 & 0.31 & 1.14 & 213.8 & 40.6 & 385.3 \\
\hline Phosphate $\left(\mathrm{PO}^{3-}\right)(\mathrm{mg} / \mathrm{L})$ & & & & 0.143 & n.d & 0.32 & & & & & & & & & \\
\hline $\begin{array}{l}\text { nitrogen-ammonia } \mathrm{NH}_{3}-\mathrm{N} \\
(\mathrm{mg} / \mathrm{L})\end{array}$ & & & & & & & 8.857 & 2 & 19 & & & & & & \\
\hline Nitrate $\mathrm{NO}^{3-}(\mathrm{mg} / \mathrm{L})$ & & & & 39.33 & 18 & 63 & & & & 3.452 & 2.75 & 4 & & & \\
\hline Nitrite $\mathrm{NO}^{2-}(\mathrm{mg} / \mathrm{L})$ & & & & & & & & & & 0.044 & 0.03 & 0.06 & & & \\
\hline Nitric oxide NO -(mg/L) & 0.61 & 0.48 & 0.81 & & & & & & & & & & & & \\
\hline References & (Al-N & $\begin{array}{r}\text { anmi \& } \\
2019)\end{array}$ & aleh, & (Al-N & $\begin{array}{l}\text { Manmi } \epsilon \\
\text { 2019) }\end{array}$ & t al., & (Alshat & $\begin{array}{l}\text { teri \& } 1 \\
\text { 2015) }\end{array}$ & lurad, & (Bar & $\begin{array}{l}\text { zinji \& G } \\
\text { 2014) }\end{array}$ & & & rhat, $2 C$ & \\
\hline
\end{tabular}

dara.muhammad@koyauniversity.org,dara.hawez@gmail.com; Nashwan.shawkat@uod.ac: shuokr.aziz@su.edu.krd,shoker71@yahoo.com; juan.sabah@yahoo.com;

shwana.manguri@uor.edu.krd1Corresponding author Department of Civil Engineering, Faculty of Engineering, Koya University Koya KOY45, Kurdistan Region - F.R. Iraq 
Table (8): Characteristics of Groundwater in Sulimani and Halabja Provinces - Part II

\begin{tabular}{|c|c|c|c|c|c|c|c|c|c|c|}
\hline \multirow{2}{*}{$\begin{array}{l}\text { Characteristics } \\
\text { Data }\end{array}$} & \multicolumn{3}{|c|}{6} & \multicolumn{3}{|c|}{7} & \multicolumn{4}{|c|}{8,9} \\
\hline & mean & Min. & Max. & mean & Min. & Max. & mean & Min. & Max. & mean \\
\hline Temperature $\left({ }^{\circ} \mathrm{C}\right)$ & & & & 18.2 & 17.4 & 19.5 & 22.05 & 20.1 & 25.5 & 19.8 \\
\hline $\mathrm{pH}$ & 7.463 & 7.23 & 7.68 & 7.8 & 7.5 & 7.9 & 7.542 & 6.8 & 8.8 & 7.8 \\
\hline Turbidity (mg/L) & 1.313 & 0.01 & 4.94 & & & & & & & \\
\hline $\mathrm{EC}(\mu \mathrm{mohs} / \mathrm{cm})$ & 537.1 & 342.5 & 796.5 & 377.9 & 357.3 & 406.7 & & & & \\
\hline Total Alkalinity (mg/L) & & & & 224.1 & 194.3 & 271.3 & & & & \\
\hline Bicarbonate alkalinity $\left(\mathrm{HCO}^{3-}\right)(\mathrm{mg} / \mathrm{L})$ & & & & & & & 333.8 & 222 & 450 & 236 \\
\hline Total Hardness (TH) (mg/L) & 660.5 & 598.2 & 760.2 & 286.3 & 265.3 & 305.3 & & & & \\
\hline -Non-carbonate hardness & & & & 64.9 & 55.3 & 74.3 & & & & \\
\hline TD solids (mg/L) & 343.7 & 219.2 & 509.8 & & & & & & & \\
\hline Chloride (Cl) (mg/L) & 23.86 & 19.5 & 29.5 & 60.9 & 55.7 & 63.7 & 51.92 & 13.8 & 110 & 5.7 \\
\hline Calcium (Ca) (mg/L) & 144.2 & 136.5 & 152.5 & 65.99 & 59.66 & 72.9 & 68.3 & 6.9 & 138 & 74.4 \\
\hline Magnesium (Mg) (mg/L) & 72.95 & 61.3 & 92.15 & 49.3 & 42.3 & 57.7 & 14.97 & 1 & 29.8 & 10.5 \\
\hline Sodium (Na) mg/L & 12.91 & 5.4 & 28.3 & 7.257 & 2.46 & 15.48 & 100.1 & 20.7 & 222 & 4.6 \\
\hline Potassium (K) mg/L & 0.807 & 0.2 & 2.26 & 1.117 & 0.89 & 1.56 & 1.425 & 0.4 & 3.9 & 1 \\
\hline Zinc (Zn) ( $\mu \mathrm{g} / \mathrm{L})$ & & & & 39.03 & 15.08 & 64.96 & 56.5 & 28.7 & 145 & 39.6 \\
\hline Cadmium (Cd) (mg/L) & & & & $2 E-05$ & 0.00001 & 4E-05 & & & & \\
\hline Chromium (Cr) ( $\mu \mathrm{g} / \mathrm{L})$ & & & & 2.92 & 2.35 & 3.92 & 0.284 & 0.02 & 1.46 & 0.42 \\
\hline Cobalt (Co) (mg/L) & & & & $1 \mathrm{E}-04$ & 0.00003 & $3 E-04$ & & & & \\
\hline Copper (Cu) (mg/L) & & & & $8 \mathrm{E}-04$ & 0.0003 & 0.001 & & & & \\
\hline Manganese $(\mathrm{Mn})(\mu \mathrm{g} / \mathrm{L})$ & & & & 11.5 & 13.23 & 20.38 & 147.9 & 0.41 & 911 & 2.76 \\
\hline Nikel (Ni) ( $\mu \mathrm{g} / \mathrm{L})$ & & & & 2.53 & 0.85 & 4.16 & 2.178 & 0.11 & 8.32 & 0.53 \\
\hline Arsenic (As) ( $\mu \mathrm{g} / \mathrm{L})$ & & & & 0.58 & 0.39 & 0.85 & 1.961 & 0.19 & 7.8 & 0.29 \\
\hline Lead $(\mathrm{Pb})(\mu \mathrm{g} / \mathrm{L})$ & & & & 0.13 & 0.23 & 0.076 & 0.068 & 0 & 0.23 & 0.07 \\
\hline Boron $(B)(\mu g / L)$ & & & & & & & 637.4 & 47.8 & 3144 & 19.6 \\
\hline Fluorine (F) (mg/L) & & & & & & & 0.338 & 0.1 & 1.65 & \\
\hline Lithium $(\mathrm{Li})(\mu \mathrm{g} / \mathrm{L})$ & & & & & & & 6.566 & 2.18 & 24.8 & 2.59 \\
\hline Aluminum (Al) $(\mu \mathrm{g} / \mathrm{L})$ & & & & 19.85 & 11.15 & 28.34 & 6.409 & 0.52 & 42 & 7.18 \\
\hline Selenium $(\mathrm{Se})(\mu \mathrm{g} / \mathrm{L})$ & & & & 0.86 & 0.58 & 1.08 & 0.287 & 0.03 & 0.91 & 0.32 \\
\hline Strontium (Sr) $\quad(\mu \mathrm{g} / \mathrm{L})$ & & & & 802.3 & 481 & 1398 & 898.8 & 294 & 1757 & 503 \\
\hline Barium (Ba) ( $\mu \mathrm{g} / \mathrm{L})$ & & & & 89.34 & 57.13 & 124.6 & 95.37 & 2.2 & 215 & 114 \\
\hline Vanadium $(V) \quad(\mu \mathrm{g} / \mathrm{L})$ & & & & 5.86 & 3.74 & 7.99 & 6.618 & 0.67 & 15.6 & 1.99 \\
\hline Uranium (U) ( $\mu \mathrm{g} / \mathrm{L})$ & & & & 1.27 & 0.98 & 1.02 & 1.301 & 0.28 & 3 & 0.65 \\
\hline Sulphate $\left(\mathrm{SO}_{4}{ }^{2-}\right)(\mathrm{mg} / \mathrm{L})$ & 78.93 & 43 & 131 & & & & 82.93 & 28.2 & 144 & 38.6 \\
\hline Phosphate $\left(\mathrm{PO}^{3-}\right)(\mathrm{mg} / \mathrm{L})$ & 0.314 & 0.2 & 0.45 & & & & 3.428 & 0.25 & 33.5 & 0.15 \\
\hline Nitrate $\mathrm{NO}^{3-}(\mathrm{mg} / \mathrm{L})$ & 5.136 & 1.5 & 8.5 & 12.6 & 9.3 & 16.1 & 6.958 & 2.4 & 25.9 & 10.4 \\
\hline Nitrite $\mathrm{NO}^{2-}(\mathrm{mg} / \mathrm{L})$ & 0.016 & 0.01 & 0.02 & & & & 0.035 & 0.003 & 0.12 & 0.04 \\
\hline References & (A. B. $)$ & nmad, 2 & 14) & (Moha & imed et al & 2018) & (Kareem & al., 2015 & areem & , 2018) \\
\hline
\end{tabular}

dara.muhammad@koyauniversity.org,dara.hawez@gmail.com; Nashwan.shawkat@uod.ac: shuokr.aziz@su.edu.krd,shoker71@yahoo.com; juan.sabah@yahoo.com;

shwana.manguri@uor.edu.krd ${ }^{1}$ Corresponding author Department of Civil Engineering, Faculty of 
Table (9): Characteristics of Groundwater in Sulimani and Halabja Provinces - Part III

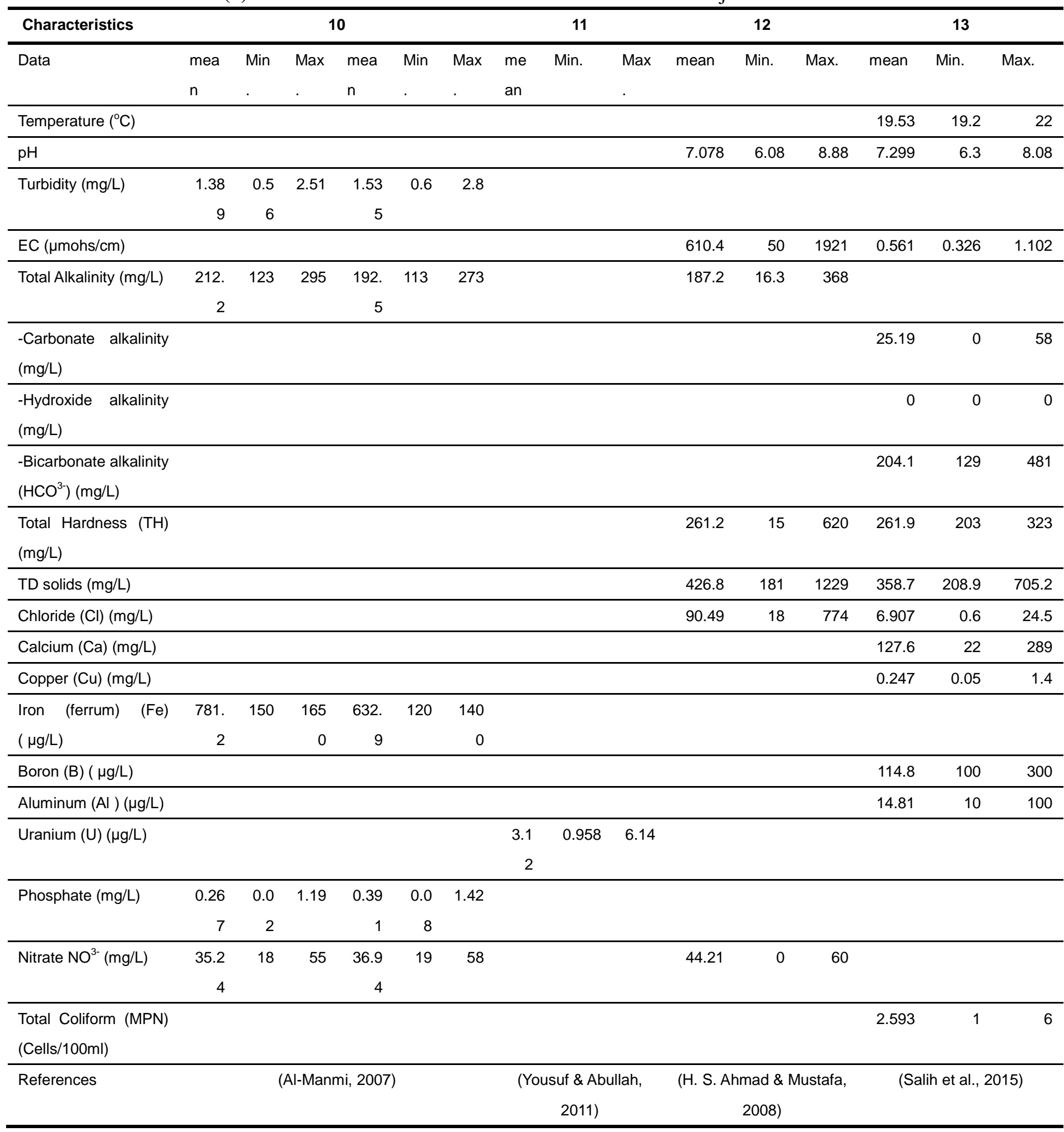

\subsubsection{Metals}

In the circumstances of water resource metals is of primary concern because they dara.muhammad@koyauniversity.org,dara.hawez@gmail.com; Nashwan.shawkat@uod.ac: shuokr.aziz@su.edu.krd,shoker71@yahoo.com; juan.sabah@yahoo.com; shwana.manguri@uor.edu.krd ${ }^{1}$ Corresponding author Department of Civil Engineering, Faculty of Engineering, Koya University Koya KOY45, Kurdistan Region - F.R. Iraq 
impact groundwater quality and, consequently, on the human (Belkhiri et al., 2018).

Groundwater will regularly recognize fair and clean because the ground normally filters out particulate matter. However, natural and human-induced chemicals can be detected in groundwater. As groundwater passes into the ground, metals such as iron are dissolved and may next be detected in considerable concentrations in the water. The other source of metals in groundwater may be Industrialized discharges, municipal activities, farming, groundwater, toxic chemical spills, Septic tank leakage, and waste disposal sites. The contamination from these sources may seep into groundwater and concentrate and migrate to the water table (Waller, 1988).

From the reviewed work in this study, groundwater in the Kurdistan Region has been tested for a broad range of metals and heavy metals. the list of metals tested in the studies are Sodium (Na), Potassium (K), Silicon (Si) ,Zinc $(\mathrm{Zn})$, ,Chromium (Cr) ,Cobalt (Co), , Iron (Fe), Manganese (Mn), Molybdenum (Mo), Nickel $(\mathrm{Ni})$, Arsenic (As) Vanadium (V) ,Lead $(\mathrm{Pb})$, Cadmium (Cd), Boron (B),Fluorine (F), Copper $(\mathrm{Cu})$,Lithium ( $\mathrm{Li})$, Aluminum ( $\mathrm{Al}$ ), Selenium (Se), Strontium ( $\mathrm{Sr}$ ), Barium (Ba), and Tellurium (Te) (Tables 4 to 11).

Because of the lower risk and concentration of some metals, the guideline value has not been established in drinking water standards.

The other metals, Sodium $(\mathrm{Na})$ has the range ( 0.85 to 16$) \mathrm{mg} / \mathrm{L}$ which is well below the WHO standard. Zinc ( $\mathrm{Zn})$ in the USEPA and Canadian standard has $5 \mathrm{mg} / \mathrm{L}$ as a guideline value. The groundwater has a lower value with is $(0.015$ to 0.419) $\mathrm{mg} / \mathrm{L}$. Further, Cadmium (Cd) has lower than the guideline value which is 0.03 by WHO (2017). Chromium (Cr) also has no risk in groundwater according to USEPA (2018), its maximum value is $0.096 \mathrm{mg} / \mathrm{L}$. However, this value is above the standard limit in WHO and Canadian Drinking water standard $(0.05 \mathrm{mg} / \mathrm{L})$. In the groundwater of the three provinces, Copper $(\mathrm{Cu})$ has not reached the maximum contaminant level according to USEPA, WHO, and Canadian Drinking water standards. Boron (B) has range (0.0063-0.0196) $\mathrm{mg} / \mathrm{L}$. This range is safe according to WHO, and Canadian Drinking water standard which is $5 \mathrm{mg} / \mathrm{L}$ and 2.4 $\mathrm{mg} / \mathrm{L}$ as a Maximum Contaminant Level respectively. Fluoride $(\mathrm{F})$ has a maximum value of $1.65 \mathrm{mg} / \mathrm{L}$ which just above limitation in WHO, and Canadian Drinking water standard, although the concentration of Fluoride $(F)$ is below of maximum contaminant level according to USEPA (2018). Besides, the maximum value of Arsenic (As), Selenium (Se), Barium (Ba) are $0.008 \mathrm{mg} / \mathrm{L}, 0.042 \mathrm{mg} / \mathrm{L}$, and $0.215 \mathrm{mg} / \mathrm{L}$. These values are safe according to WHO, Canadian Drinking water standard, and USEPA. Overall, metals and heavy metals are under safe limitations in groundwater in the Kurdistan region.

\subsubsection{Phosphate, and Sulphate}

Phosphates and sulfates share relationships in that both are salts of acids and both occur in nature as minerals. However, their molecular structures vary, they form from various acids, they comprise different minerals and they serve different purposes.

Phosphorus is a highly reactive element, vital to life and creating a variety of compounds in worldly and marine ecosystems. Phosphorus may appear in water as the orthophosphate (Domagalski \& Johnson, 2012).

Presently, investigation and management on diffuse source phosphate have concentrated on movements of phosphate from farming field to surface waters via seepage and surface runoff in rainfall events (Heathwaite et al., 2005; Withers \& Haygarth, 2007). Minimal study to date has been given attention to estimating transfers via

dara.muhammad@koyauniversity.org,dara.hawez@gmail.com; Nashwan.shawkat@uod.ac: shuokr.aziz@su.edu.krd,shoker71@yahoo.com; juan.sabah@yahoo.com;

shwana.manguri@uor.edu.krd ${ }^{1}$ Corresponding author Department of Civil Engineering, Faculty of Engineering, Koya University Koya KOY45, Kurdistan Region - F.R. Iraq 
groundwater. (Heathwaite et al., 2006; Kilroy \& Coxon, 2005). Although orthophosphate is dissolvable in water, it can tie or adsorb onto soil particles. At the time a soil nears or arrives saturation, dissolved phosphorus can be moved to deeper portions of the unsaturated zone and into the groundwater (Domagalski \& Johnson, 2012).

Guidelines for Canadian Drinking Water Quality suggest $0.02 \mathrm{mg} / \mathrm{L}$ for the maximum acceptable concentration of phosphate in water. The reviewed studies the range of phosphate is from $0.02 \mathrm{mg} / \mathrm{L}$ to $1.67 \mathrm{mg} / \mathrm{L}$ and all the values are higher than the maximum acceptable concentration.

Sulfate was found in many aquifers and surface water at significant concentrations. Sulfate is a type of Sulphur that is oxidized. In the process of mining of sulfide, Sulphur changes to sulfate in the presence of oxygen. Another source of sulfate is Gypsum, which is available in certain aquifers. (Agency, 1999b). Minerals of sulfate can induce scale accumulation in water pipes comparable to other minerals and may be correlated with a bitter taste in water that may have a laxative impact on humans and young animals (Oram, 2014). Ingestion of $7 \mathrm{~g}$ magnesium sulphate and $8 \mathrm{~g}$ sodium sulphate induced catharsis in adult males. (Cocchetto \& Levy, 1981; Morris \& Levy, 1983). Cathartic effects are generally defined as felt by people consuming sulphate-containing drinking water at concentrations greater than $600 \mathrm{mg} / \mathrm{liter}$. (Service, 1962), Although it is believed that humans will adapt to more intense concentrations over time. Dehydration was also identified as a common side-effect after ingestion of significant amounts of magnesium (USEPA, 1985) or sodium sulphate (Fingl, 1980).

Sulfate has a maximum acceptable concentration $500 \mathrm{mg} / \mathrm{L}$ (Canada et al., 2019), and maximum contaminant level equal to 250 $\mathrm{mg} / \mathrm{L}$ in USEPA (2018), but not of health concern at levels found in drinking-water for sulfate in WHO (2017).

For the analyzed sample in the reviewed studies, sulfate has a limit (0.31 to 716$) \mathrm{mg} / \mathrm{L}$. Many studied areas have sulfate concentration above the guideline value of Canada et al., 2019), and USEPA (2018) standards (Tables 4 to 11)

\subsubsection{Nitrate $\mathrm{NO}_{3-}$ and Nitrite $\mathrm{NO}_{2-}$}

While nitrite is usually missing or present in groundwater to a far smaller degree as it is readily converted into nitrate, nitrite $\left(\mathrm{NO}_{2}\right)$ is an associated contaminant that has identical physical properties to nitrate, linked with nitrate and nitrate sources (CDPH, 2013).

Nitrate is colorless and odorless, odorless liquid, and without taste, it is available in low amounts of naturally occurring nitrate may be common, but excess concentrations may contaminate groundwater. This may have serious health consequences.

Conventional nitrate origins in groundwater from fertilizers, agricultural waste, and human waste related to septic and municipal sanitation systems. Extra nitrate is usually found in the soil of rural and industrial areas. Nitrate quickly passes into groundwater through rain or irrigation water. Wells in agricultural areas that are shallow, found in sandy soil or badly constructed or repaired wells are more vulnerable to nitrate pollution (CDPH, 2013).

High concentration of Nitrate may contribute to possible environmental and public health risks. High Nitrate concentrations are believed to promote heavy algal growth thus promoting the eutrophication in water bodies (Bhatnagar \& Sillanpää, 2011). Rise of Nitrate concentrations of portable water causes two adverse health effects in humans, body : development of "blue-baby syndrome" (methemoglobinemia), particularly in children, and the possible

dara.muhammad@koyauniversity.org,dara.hawez@gmail.com; Nashwan.shawkat@uod.ac: shuokr.aziz@su.edu.krd,shoker71@yahoo.com; juan.sabah@yahoo.com; 
production of carcinogenic nitrosamines (Majumdar \& Gupta, 2000; Tate \& Arnold, 1990). Recent research (Islam \& Patel, 2010) and references to it have shown that excess Nitrate in drinking water may also cause different forms of human cancer (Bhatnagar \& Sillanpää, 2011).

Nitrate and Nitrite standard value in $10 \mathrm{mg} / \mathrm{L}$ and $1 \mathrm{mg} / \mathrm{L}$ in USEPA (2018),Also WHO (2017) guideline value for Nitrate and Nitrite is $50 \mathrm{mg} / \mathrm{L}$ and $3 \mathrm{mg} / \mathrm{l}$ respectively. In Canada et al. (2019) maximum acceptable concentration for Nitrate is $45 \mathrm{mg} / \mathrm{L}$ and for Nitrite equal to $3 \mathrm{mg} / \mathrm{L}$.

From the reconsidered studies, Nitrate has a range (1-58) $\mathrm{mg} / \mathrm{L}$ and Nitrite has $(0.01-2) \mathrm{mg} / \mathrm{L}$ comparing these results to the above standard, it shows that groundwater in some locations in the Kurdistan region contaminated with Nitrate and Nitrite (Tables 4 to 11).

\subsubsection{Uranium}

Uranium is a radioactive element that happens naturally, and appears anywhere in our world. All of which include uranium, atmospheric dust, food, soil, rocks and natural waters. Notwithstanding that, in most situations, it is uranium in water that governs our everyday access to the chemical. It is particularly the case when potable water is obtained directly from groundwater. Uranium is a mixture of three isotopes, $238 \mathrm{U}, 235 \mathrm{U}$ and $234 \mathrm{U}$, all three chemically behave the same, but they have different radioactive characteristics. (Sharma \& Rishi, 2016). Uranium is widespread in the environment as a result of leaching from natural deposits, release into mill tailings, nuclear industry emissions, the combustion of coal and other fuels and the use of uranium-carrying phosphate fertilizers (Organization, 2005). Furthermore, Uranium contamination of groundwater occurs from the aquifer (Hess et al., 1985; Sharma \& Rishi, 2016).

After ingestion, uranium immediately arrives in the bloodstream (La Touche et al., 1987), where it is basically connected with the red cells (Fisenne \& Perry, 1985); a non-diffusible uranyl-albumin compound also produces a diffusable ionic uranyl hydrogen carbonate compound in the plasma. (Moss, 1985). Uranyl compounds quickly combine with proteins and nucleotides to create stable complexes due to their strong affinity for phosphate, carboxyl, and hydroxyl groups (Moss, 1985) Blood clearance is similarly rapid, and the uranium then collects in the kidneys and skeletons, so while little is noticed in the liver (La Touche et al., 1987). The skeleton is the principal site of accumulation of uranium (Wrenn et al., 1985); The uranyl ion modifies calcium in bone crystals in the hydroxyapatite complex (Moss, 1985).

Maximum Contaminant Level for Uranium in USEPA equals to $0.03 \mathrm{mg} / \mathrm{L}$. in a study by Mohammed, Karim, \& Mohammed, (2018) stated that maximum and minimum value Uranium in Halabja is 1.27 and $0.98(\mu \mathrm{g} / \mathrm{L})$. Also, Yousuf \& Abdullah, (2011) found a range of the Uranium concentration in waster ground in the city and around is ( 0.958 to 3.12$)(\mu \mathrm{g} / \mathrm{L})$. These values indicate that groundwater in the studied area is clean concerning the Uranium element (Tables 4 to 11).

dara.muhammad@koyauniversity.org,dara.hawez@gmail.com; Nashwan.shawkat@uod.ac: shuokr.aziz@su.edu.krd,shoker71@yahoo.com; juan.sabah@yahoo.com; shwana.manguri@uor.edu.krd ${ }^{1}$ Corresponding author Department of Civil Engineering, Faculty of Engineering, Koya University Koya KOY45, Kurdistan Region - F.R. Iraq 
Table (10): Characteristics of Groundwater in Duhok Province - Part I

\begin{tabular}{|c|c|c|c|c|c|c|c|c|c|}
\hline \multirow[t]{3}{*}{ Characteristics } & \multicolumn{3}{|c|}{1} & \multicolumn{6}{|c|}{2} \\
\hline & \multirow[b]{2}{*}{ Mean } & \multirow[b]{2}{*}{ Min } & \multirow[b]{2}{*}{ Max } & \multicolumn{3}{|c|}{ Dry season } & \multicolumn{3}{|c|}{ Wet season } \\
\hline & & & & Mean & Min & Max & Mean & Min & Max \\
\hline $\mathrm{pH}$ & & & & 7.16 & 6.95 & 7.43 & 7.38 & 7.25 & 7.52 \\
\hline Turbidity (mg/L) & & & & 0.04 & 0.03 & 0.06 & 0.03 & 0.02 & 0.05 \\
\hline Total Alkalinity (mg/L) & & & & 283 & 244 & 317 & 342 & 306 & 370 \\
\hline Total Hardness) (mg/L) & & & & 361 & 304 & 425 & 373 & 339 & 439 \\
\hline TD solids (mg/L) & & & & 478 & 392 & 539 & 462 & 385 & 536 \\
\hline Chloride (Cl) (mg/L) & & & & 19.5 & 15.7 & 23.3 & 33.4 & 24.3 & 39.2 \\
\hline Calcium (Ca) (mg/L) & & & & 79.4 & 53.7 & 90.4 & 79.5 & 73.2 & 90 \\
\hline Magnesium (Mg) (mg/L) & & & & 39.5 & 28.1 & 51.1 & 42.4 & 33.4 & 54 \\
\hline Sodium (Na) mg/L & & & & 2.64 & 0.93 & 6.62 & 6.34 & 2.95 & 15 \\
\hline Potassium (K) mg/L & & & & 1.36 & 0.64 & 3.55 & 1.9 & 1.05 & 3.78 \\
\hline Sulphate $\left(\mathrm{SO}_{4}{ }^{2-}\right)(\mathrm{mg} / \mathrm{L})$ & & & & 99.2 & 78.5 & 132 & 65.3 & 27.3 & 116 \\
\hline Nitrate NO3 (mg/L) & & & & 2.58 & 2.18 & 3.17 & 2.81 & 2.27 & 3.14 \\
\hline Total Coliform (MPN) (Cells/100ml) & 65.3 & 46 & 99 & & & & & & \\
\hline Faecal coliform (cells/100ml) & 36.3 & 0 & 99 & & & & & & \\
\hline Bacterial concentration (cfu. mL-1) & 1466 & 938 & 1950 & & & & & & \\
\hline Fecal Streptococci (\%) & 40.5 & 0 & 97 & & & & & & \\
\hline References & $\begin{array}{l}\text { (Al-Mezori } \\
2011 \text { ) }\end{array}$ & $\&$ & Hawrami, & & & (Amee & , 2019) & & \\
\hline
\end{tabular}

Table (11): Characteristics of Groundwater in Duhok Province - Part II

\begin{tabular}{|c|c|c|c|c|c|c|c|c|c|}
\hline \multirow[t]{2}{*}{ Characteristics } & \multicolumn{3}{|c|}{3} & \multicolumn{3}{|c|}{4} & \multicolumn{3}{|c|}{5} \\
\hline & Mean & Min & Max & Mean & Min & Max & Mean & Min & Max \\
\hline Temperature $\left({ }^{\circ} \mathrm{C}\right)$ & & & & 16.2 & 13.1 & 18.7 & & & \\
\hline $\mathrm{pH}$ & 7.61 & 7.42 & 7.98 & 7.21 & 6.6 & 8.5 & & & \\
\hline $\mathrm{EC}(\mu \mathrm{mohs} / \mathrm{cm})$ & 596 & 380 & 870 & 580 & 330 & 926 & & & \\
\hline Total Hardness (mg/L) & & & & 321 & 173 & 537.7 & & & \\
\hline TD solids (mg/L) & & & & 372 & 207 & 582.3 & & & \\
\hline Dissolved oxygen DO (mg/L) & & & & 7.59 & 6.73 & 8.4 & & & \\
\hline Chloride (Cl) (mg/L) & & & & 40.3 & 22.3 & 66.63 & 19.37 & 8.03 & 37.67 \\
\hline Zinc (Zn) ( $\mu g / L)$ & 36 & 24 & 45 & 353 & ND & 419 & 203.8 & 108 & 421 \\
\hline Cadmium (Cd) ( $\mu \mathrm{g} / \mathrm{L})$ & 4.93 & 4.05 & 6.05 & 3.67 & ND & 14 & 4.23 & 2.3 & 8.5 \\
\hline Chromium (Cr) ( $\mu \mathrm{g} / \mathrm{L})$ & 7.89 & 5.05 & 14.5 & 1.29 & ND & 2 & 0.0001 & 0.0001 & 0.0001 \\
\hline Cobalt (Co) ( $\mu \mathrm{g} / \mathrm{L})$ & & & & 1.86 & ND & 3 & 0.062 & $1 \mathrm{E}-04$ & 0.17 \\
\hline Copper (Cu) ( $\mu \mathrm{g} / \mathrm{L})$ & 3.5 & 3.1 & 3.9 & 34.4 & ND & 67 & 242.5 & 206 & 376 \\
\hline Iron (ferrum) $(\mathrm{Fe})(\mu \mathrm{g} / \mathrm{L})$ & & & & 21.4 & ND & 41 & 10.63 & 5.5 & 16.2 \\
\hline Manganese (Mn) ( $\mu \mathrm{g} / \mathrm{L})$ & & & & 2.27 & ND & 6 & 25.33 & 15.4 & 76.6 \\
\hline
\end{tabular}

dara.muhammad@koyauniversity.org, dara.hawez@gmail.com; Nashwan.shawkat@uod.ac:

shuokr.aziz@su.edu.krd,shoker71@yahoo.com; juan.sabah@yahoo.com;

shwana.manguri@uor.edu.krd ${ }^{1}$ Corresponding author Department of Civil Engineering, Faculty of

Engineering, Koya University Koya KOY45, Kurdistan Region - F.R. Iraq 


\begin{tabular}{lccccccccc}
\hline Nikel $(\mathrm{Ni})(\mu \mathrm{g} / \mathrm{L})$ & 28.9 & 23 & 36 & 14.1 & $\mathrm{ND}$ & 28 & 50.59 & 16.5 & 71.7 \\
\hline Arsenic $(\mathrm{As})(\mu \mathrm{g} / \mathrm{L})$ & 3.16 & 0.7 & 8 & & & & & & \\
\hline Lead $(\mathrm{Pb})(\mu \mathrm{g} / \mathrm{L})$ & 72.4 & 62 & 89.5 & 52 & $\mathrm{ND}$ & 101 & 2.664 & 0.742 & 4 \\
\hline Sulphate $\left(\mathrm{SO}_{4}{ }^{2-}\right)(\mathrm{mg} / \mathrm{L})$ & & & & 37.7 & 16.3 & 60.13 & 8.879 & 2.83 & 28.63 \\
\hline Nitrate $\mathrm{NO}^{3-}(\mathrm{mg} / \mathrm{L})$ & & & 2.55 & 1 & 4.9 & 15.37 & 5.13 & 55.33 \\
\hline References & (Hawrami \& Mezuri, 2014) & (Umer et al., 2020) & & (Umer et al., 2018) \\
\hline
\end{tabular}

\subsection{Spatial Interpolation}

Spatial interpolation is the method of using points with known values to predict values at other points. A spatial interpolation in the geosciences is the estimation of a two or three-dimensional manifold across a study region from measurements taken at known locations in the area (Zimmerman et al., 1999). The fore, Spatial interpolation methods are frequently used to estimate values of physical or chemical constituents in locations where they are not measured (Murphy, Curriero, \& Ball, 2010). For point interpolation, the various methods may further be classified into exact and approximate. Methods that constitute ordinary and universal kriging, inverse distance weighting, interpolating polynomials, splines, and power and Fourier series fitting (Lam, 1983).

The variety of available interpolation methods has led to questions about which is perfect. Unfortunately, published researches are not as straightforward as to which interpolation method is most accurate. In some studies (Laslett, 1994; Phillips et al., 1997; Weber \& Englund, 1994) a kriging procedure performed best, while in others (Brus et al., 1996; Declercq, 1996; Gallichand \& Marcotte, 1993) splines or inverse distance weighting were as good or better. After, several important points emerge from the results of the previous section. Zimmerman, Pavlik, Ruggles, \& Armstrong, (1999) concluded that the kriging method has consistently and substantially outperformed and kriging method has several other advantages over other methods. Therefore, the kriging method will be used for investigation and interpolation of the following groundwater parameters over the indicated locations.

From the above part of the discussion, the groundwater quality has some outrange in some parameters such as $\mathrm{pH}$-value, Turbidity, Total Dissolved Solids, Electrical conductivity (EC), Total Alkalinity (TA), Total Hardness (TH) , Phosphate, Sulphate and, Nitrate. Hence, the critical parameters will be chosen to establish a map by the kriging method. This will help to predict the value of critical characterizes in outside of the studies area.

The list of substances shown in the area of the studies, Erbil City, Sulimani City, Darbandikhan, and Kifri, this will help understand the predicted groundwater pollution areas in the location (Fig 4 to 12).

\subsubsection{Erbil City}

About Erbil City, pH-Value, total alkalinity, and turbidity have been chosen as a critical parameter. These water properties were taking from inside Erbil City, landfilled site, a Kawergosk refinery based on studies Daham et al. (1998), Aziz and Maulood (2015) and Aziz and Fakhrey (2016).

Using ArcGIS software, maps were created for these characterizes (Fig. 4 to 6). The $\mathrm{pH}$-value was shown in figure 4. The range for $\mathrm{pH}$ was 7.2 to 8.9. The highest value of $\mathrm{pH}$ can be seen in the east of the City. The total alkalinity was found to be in the range of 180

dara.muhammad@koyauniversity.org,dara.hawez@gmail.com; Nashwan.shawkat@uod.ac: shuokr.aziz@su.edu.krd,shoker71@yahoo.com; juan.sabah@yahoo.com; shwana.manguri@uor.edu.krd ${ }^{1}$ Corresponding author Department of Civil Engineering, Faculty of Engineering, Koya University Koya KOY45, Kurdistan Region - F.R. Iraq 
$\mathrm{mg} / \mathrm{L}$ to $400 \mathrm{mg} / \mathrm{L}$. The middle and north-east of the City have the highest concentration of total alkalinity (Fig.5). Similarly, most turbid water can be found in the central and north-east of the City (Fig.6) The ornundwater near anaernhic
Erbil Landfill Site (ELS)contaminated due to leachate formed from ELS and groundwater characteristics around the Kawergosk Oil Refinery may slightly be polluted.

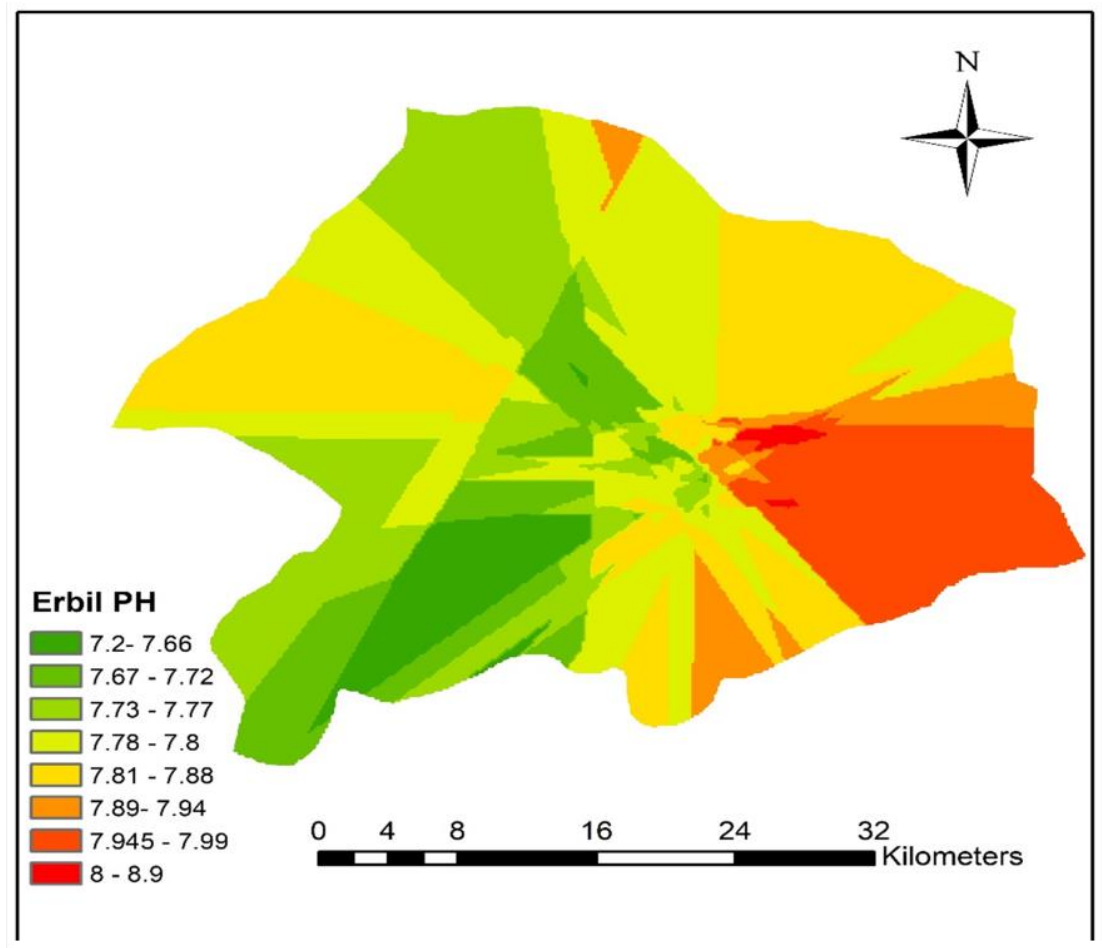

Fig. (4): Spatial distribution of pH-value in groundwater in Erbil City

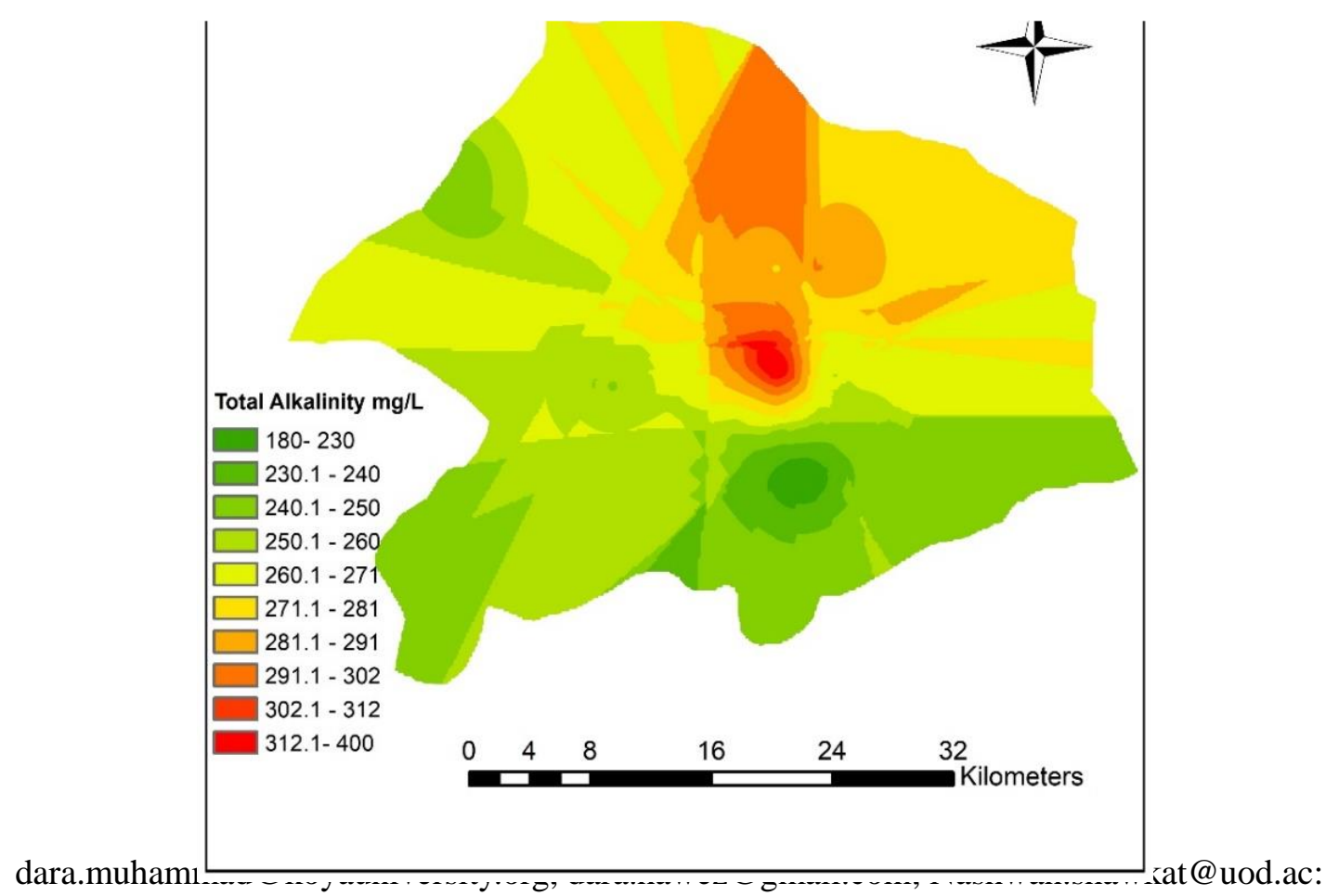

shuok Fig. (5): Spatial distribution total alkalinaty in groundwater in Erbil City rom;

shwana.mangurı w uor.euu.kru Corresponaing autnor vepartment or Livıl engıneerıng, Faculty of Engineering, Koya University Koya KOY45, Kurdistan Region - F.R. Iraq 


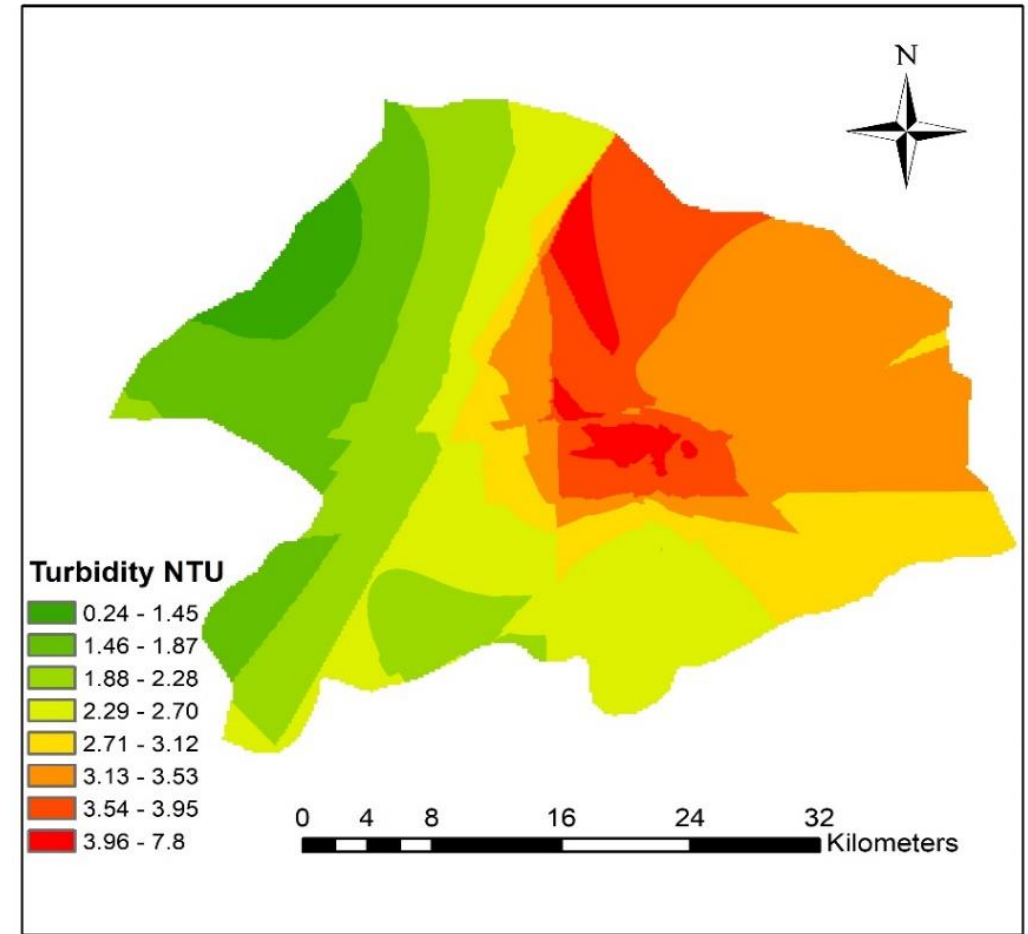

Fig. (6): Spatial distribution turbidity in groundwater in Erbil City

\subsubsection{Sulimani City}

Based on Studies Kareem et al. (2015), Kareem et al. (2018) , and H. S. Ahmad and Mustafa (2008), Sulimani City has recorded a high value of $\mathrm{pH}$, Nitrate, and Phosphate. The Spatial Interpolation maps were created for these parameters (Fig.7 to 9).

Most parts of Sulimani City have $\mathrm{pH}$-Value in range 6.8 to 7.7. However, the Tanjero area showed some high $\mathrm{pH}$ value, which can be seen in the middle of figure .7. North part of the City seems to be had more Phosphate contrast to the south. In Center and north-west of the City recorded the most significant value of Phosphate $1.8 \mathrm{mg} / \mathrm{l}$ to $2.8 \mathrm{mg} / \mathrm{L}$ (Fig.8) For Nitrate, groundwater in North-east of Sulimani shows more concertation compare to other parts.

The high value of some parameters may happen due to scraping and dumpsites in the Tanjero area (Kareem et al., 2015; Kareem et al., 2018). However, the majority of the water wells are polluted with Nitrate. The main source of this pollution in the groundwater comes from sewages (H. S. Ahmad \& Mustafa, 2008).

dara.muhammad@koyauniversity.org,dara.hawez@gmail.com; Nashwan.shawkat@uod.ac: shuokr.aziz@su.edu.krd,shoker71@yahoo.com; juan.sabah@yahoo.com; shwana.manguri@uor.edu.krd ${ }^{1}$ Corresponding author Department of Civil Engineering, Faculty of Engineering, Koya University Koya KOY45, Kurdistan Region - F.R. Iraq 


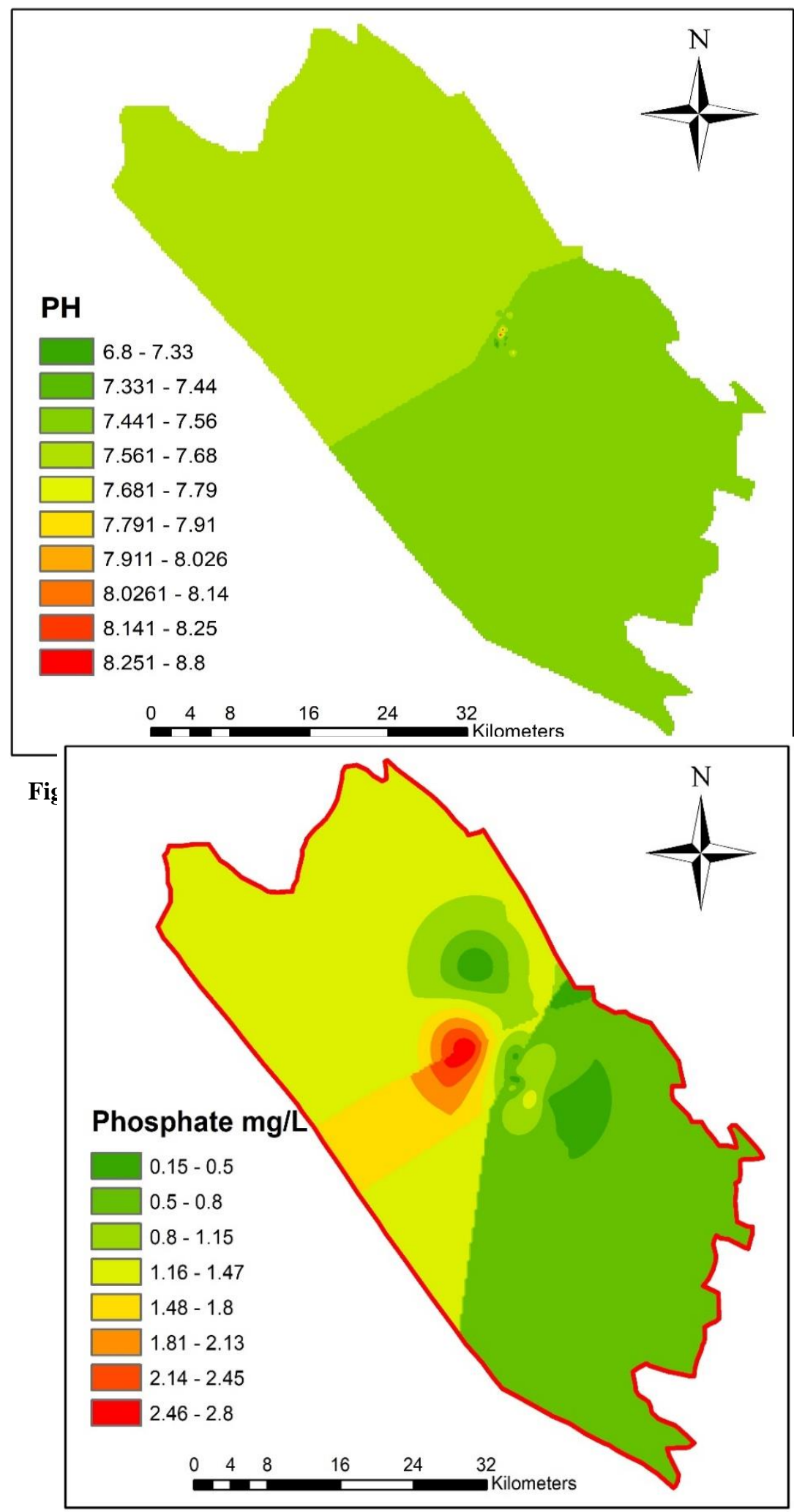

Fig. (8): Spatial distribution of Phosphate in groundwater in Sulimani City

dara.muhammad@koyauniversity.org,dara.hawez@gmail.com; Nashwan.shawkat@uod.ac: shuokr.aziz@su.edu.krd,shoker71@yahoo.com; juan.sabah@yahoo.com; shwana.manguri@uor.edu.krd ${ }^{1}$ Corresponding author Department of Civil Engineering, Faculty of Engineering, Koya University Koya KOY45, Kurdistan Region - F.R. Iraq 


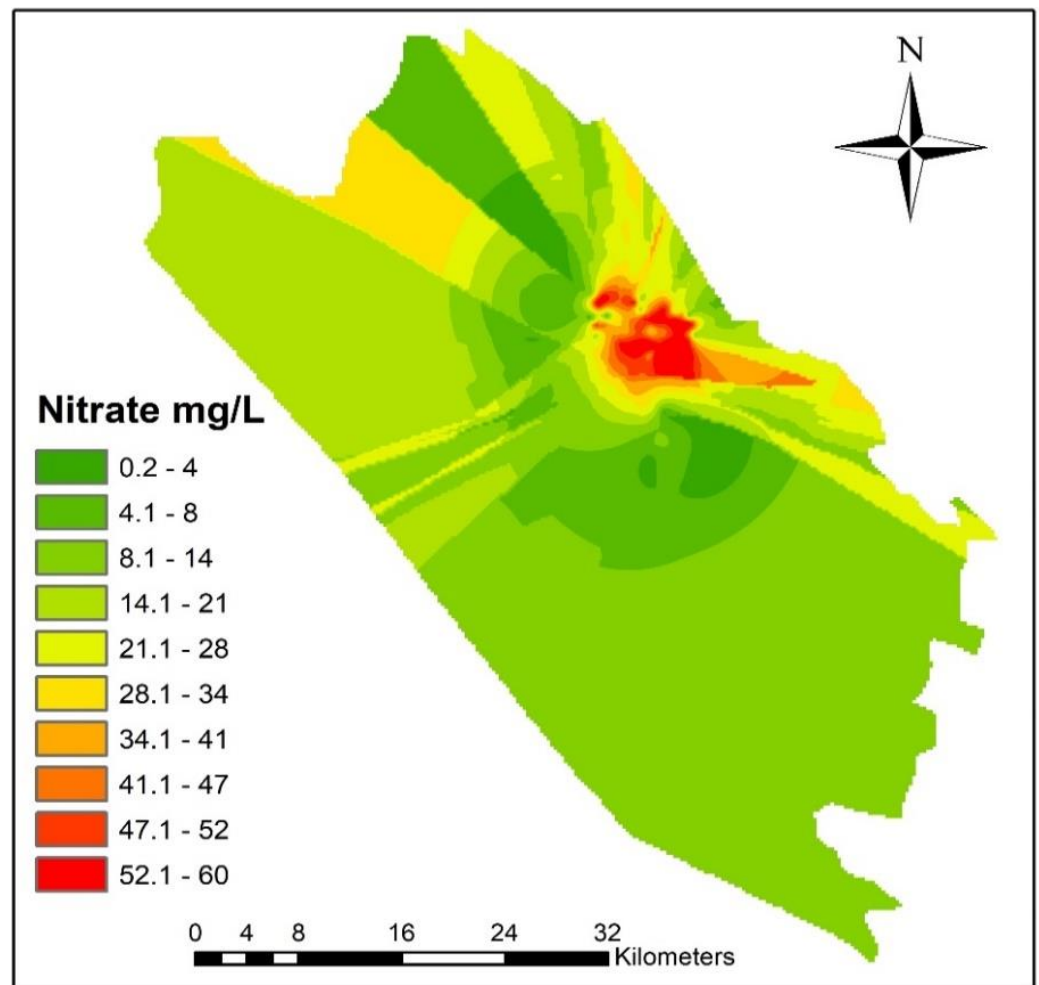

Fig. (9): Spatial distribution of Nitrate in groundwater in Sulimani City

\subsubsection{Darbandikhan District}

In Darbandikhan, Phosphate and total alkalinity were tested by A. B. Ahmad (2014)Though this study, Phosphate and total alkalinity parameters shown as a high concentration in some parts of the District (Fig 10 to 11$)$.

Groundwater has more concentration in the south part of the District ( 0.3 to 0.45 ) $\mathrm{mg} / \mathrm{L}$. Likewise, the groundwater in the southern part of Darbandikhan is more alkane compare to other regions (Fig 10 to 11 ). The high value of some water characteristics may relate to the soil formation within the study area (A. B. Ahmad, 2014).

dara.muhammad@koyauniversity.org,dara.hawez@gmail.com; Nashwan.shawkat@uod.ac: shuokr.aziz@su.edu.krd,shoker71@yahoo.com; juan.sabah@yahoo.com; shwana.manguri@uor.edu.krd ${ }^{1}$ Corresponding author Department of Civil Engineering, Faculty of Engineering, Koya University Koya KOY45, Kurdistan Region - F.R. Iraq 


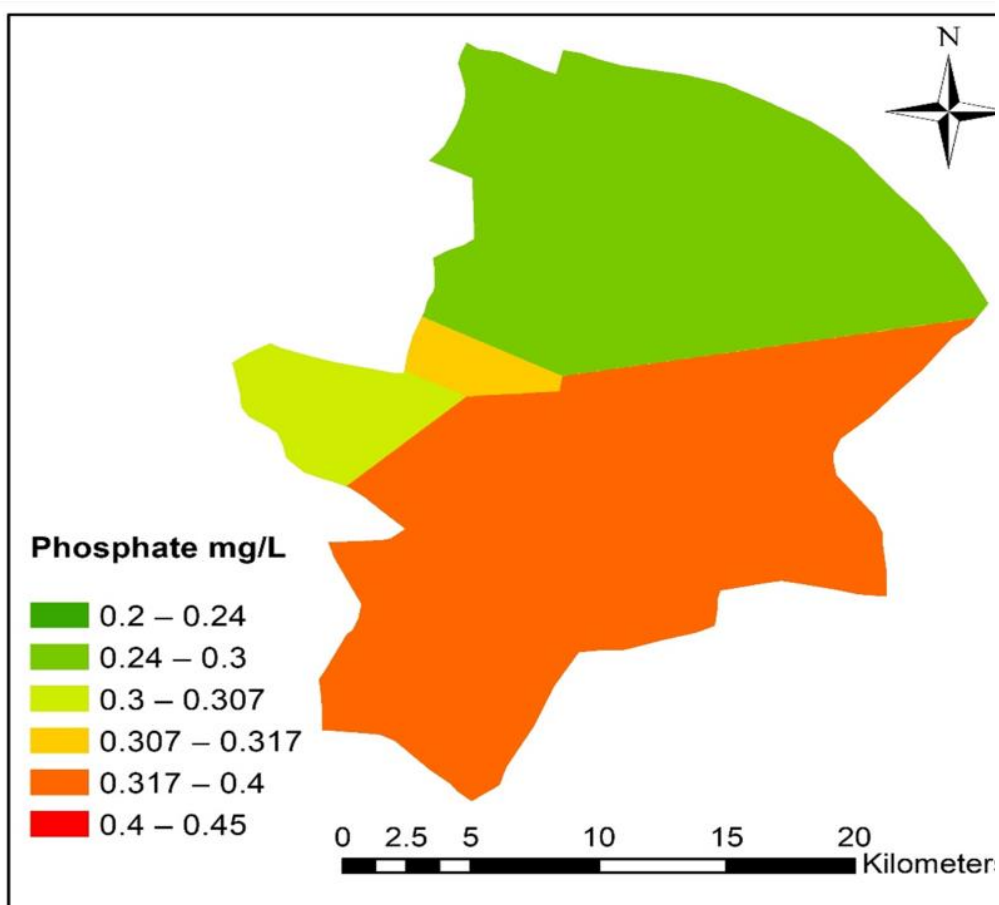

Fig. (1): Spatial distribution of Phosphate in groundwater in Darbandikhan

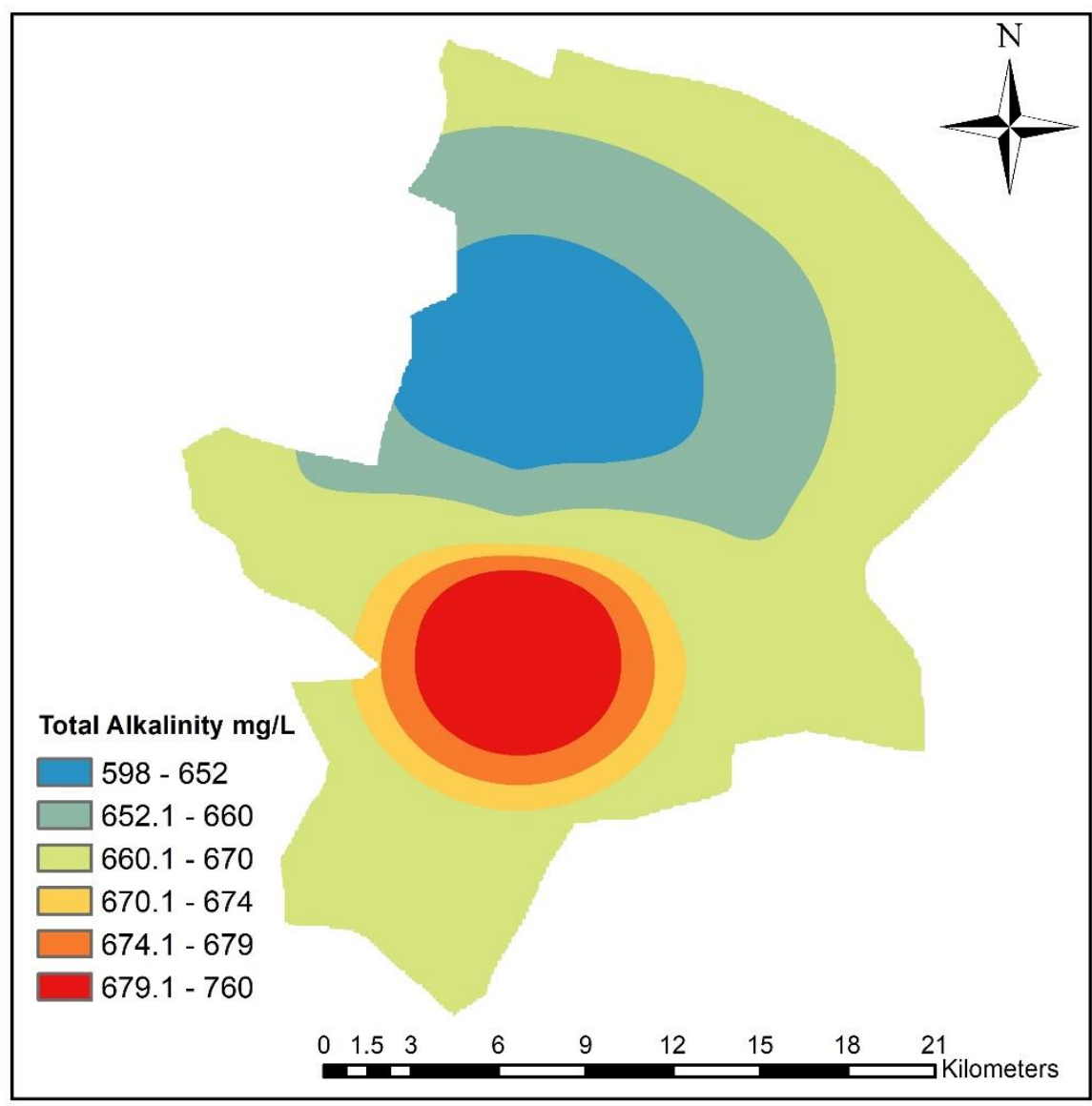

Fig. (10): Spatial distribution of total alkalinity in groundwater in Darbandikhan District.

dara.muhammad@koyaunıversity.org, dara.hawez@gma1l.com; Nashwan.shawkat@uod.ac: shuokr.aziz@su.edu.krd,shoker71@yahoo.com; juan.sabah@yahoo.com; shwana.manguri@uor.edu.krd ${ }^{1}$ Corresponding author Department of Civil Engineering, Faculty of Engineering, Koya University Koya KOY45, Kurdistan Region - F.R. Iraq 


\subsubsection{Kifri District}

In Kifri District ,pH value has outrange ( 7.2 to 8.8) (Sarhat, 2017).Therefore, the Spatial distribution was created to predict the-Value in the District (Fig .12). From the kriging interpolation method, groundwater in south east has of Kifri has $\mathrm{pH}$ value in range (8.2 to 8.8). The $\mathrm{pH}$ values of the groundwater indicate that the groundwater in the study area is slightly alkaline in nature. That is because of the $\mathrm{HCO} 3$ influx in the groundwater aquifer as a result of rain water percolation through soil (Sarhat, 2017).

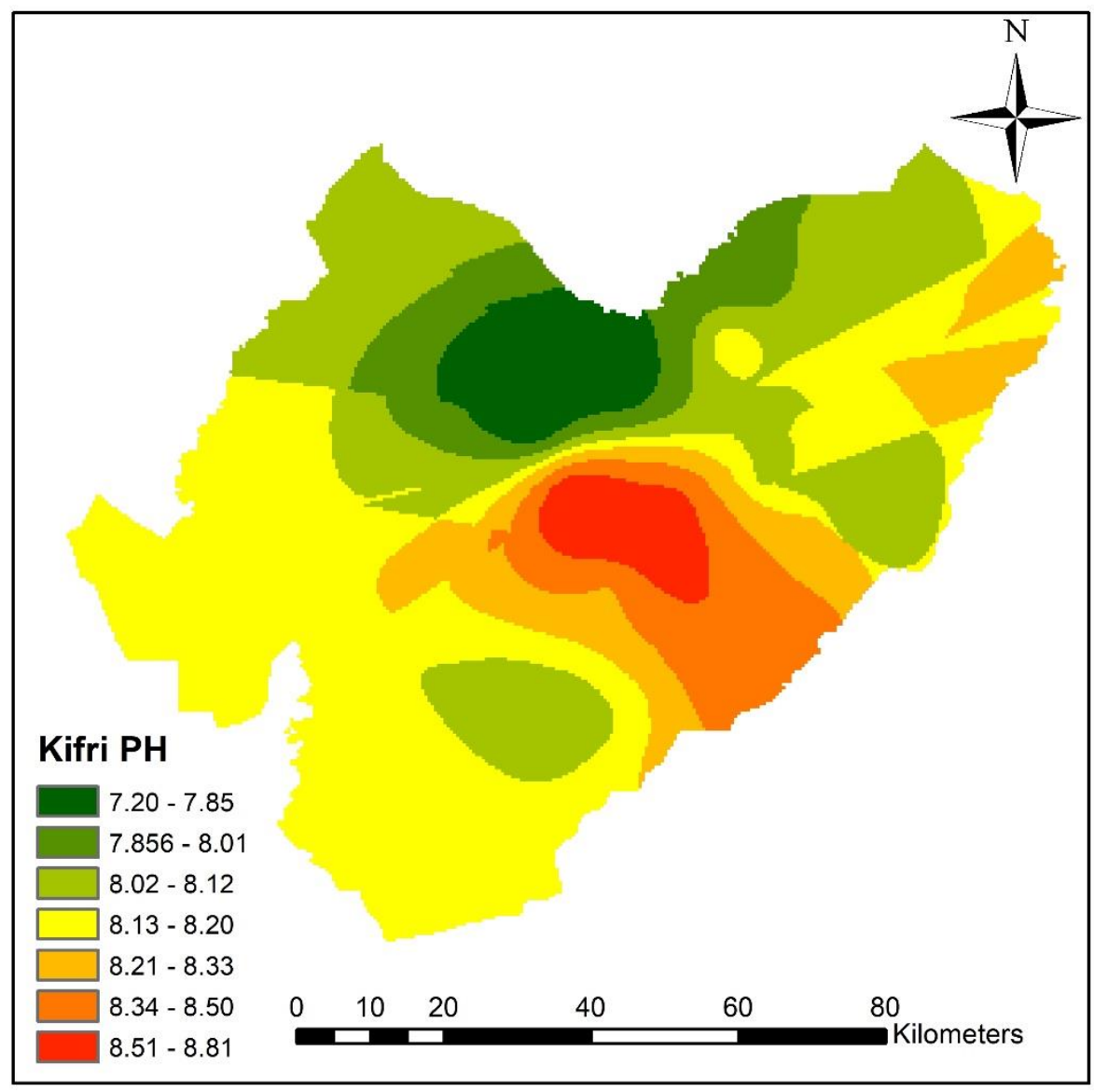

Fig. (11): Spatial distribution of $\mathrm{pH}$-value in groundwater in Kifri District

\section{CONCLUSIONS}

Kurdistan Region is faced with different groundwater issues, such as springs and several wells illegal that have dried up due to drought weather in past years. Besides, that enplaned the industrial sector has a severe impact on groundwater by using groundwater for its production and discarding the contaminated water without any treatment.

The reviewed studies have targeted different locations in these four provinces. However, some districts and towns in theses provinces have not been selected by any studies yet.

dara.muhammad@koyauniversity.org,dara.hawez@gmail.com; Nashwan.shawkat@uod.ac: shuokr.aziz@su.edu.krd,shoker71@yahoo.com; juan.sabah@yahoo.com; 
Therefore, the quality of groundwater in these areas not know. Besides that, location of the wells, springs and karizes are not entirely geometrically distributed in studied zones; therefore, some parts in the cities and districts are not thoroughly investigated.

The WHO, USEPA, and Canadian drinking water quality standards were used to assess the groundwater of the Kurdistan Region. Commonly the groundwater contaminated in some areas in Kurdistan Region, and generally, it can be used for drinking and domestic uses after-treatment process. Some area has been faced with contamination with a different substance.

The kriging interpolation method was used for showing the area of the study with pollutants. This method has not been used for all the reviewed studies because of the limitation of these studies' data. Those studies have been used in creating Spatial distribution, has some issues regarding data distribution in the study area. The data may take part in the city of the spatial zone in a district so that the rest of the areas are left for prediction. Therefore, more studies can be recommended for though areas, which are not investigated yet.

\section{REFERENCES}

Abdullah, T., Ali, S., Al-Ansari, N., \& Knutsson, S. (2016). Groundwater Vulnerability Using DRASTIC and COP Models: Case Study of Halabja Saidsadiq Basin, Iraq. Engineering, 8, 741-760. doi:10.4236/eng.2016.811067

Agency, M. P. C. (1999a). Chloride and Fluoride in Minnesota's Ground Water. Saint Paul,: Minnesota Pollution Control Agency,

Agency, M. P. C. (1999b). Sulfate in Minnesota's Ground Water. Saint Paul,: Minnesota Pollution Control Agency,

dara.muhammad@koyauniversity.org,dara.hawez@gmail.com; Nashwan.shawkat@uod.ac: shuokr.aziz@su.edu.krd,shoker71@yahoo.com; juan.sabah@yahoo.com; shwana.manguri@uor.edu.krd ${ }^{1}$ Corresponding author Department of Civil Engineering, Faculty of Engineering, Koya University Koya KOY45, Kurdistan Region - F.R. Iraq
Ahmad, A. B. (2014). Evaluation of Groundwater Quality Index for drinking purpose from some villages around Darbandikhan district, Kurdistan Region -Iraq. IOSR Journal of Agriculture and Veterinary Science (IOSR-JAVS), $\quad 7(9), \quad 8$. doi:10.9790/2380-07913441

Ahmad, H. S., \& Mustafa, O. M. (2008). Nitrate Pollution in Groundwater of Sulaimaniyah City, Kurdistan Region, NE Iraq. Iraqi Bulletin of Geology Mining, 4(2), 10.

Akhtar, M. M., Tang, Z., \& Mohamadi, B. (2014). Contamination potential assessment of potable groundwater in Lahore, Pakistan. Polish Journal of Environmental Studies, 23(6), 1905-1916.

Al-Ansari, N., Ali, A., \& Knutsson, S. (2014). Present conditions and future challenges of water resources problems in Iraq. Water Resource and Protection, 6(12), 1066-1098.

Al-Barwary, M., Meshabaz, R., Hussein, N., \& Ali, N. (2018). A Comparison of water quality between well and spring samples selected from Soran District, Northern Erbil Governorate, Kurdistan Region - Iraq. Paper presented at the IOP Conference Series: Materials Science and Engineering.

Al-Manmi, D. A. (2007). Groundwater Quality Evaluation in KalarTown-Sulaimani/NE -Iraq Iraqi National Journal of Earth Sciences, 7(2), 22.

Al-Manmi, D. A., Hamamin, D. F., \& Salih, A. O. (2019). KAREZES, ABANDONED AND ENDANGERED WATER RESOURCES IN SEMI-ARID REGIONS: CASE STUDY FROM SULAYMANIYAH CITY, IRAQ. Iraqi Bulletin of Geology Mining, 15(1), 14.

Al-Manmi, D. A., \& Saleh, K. A. (2019). Delineation of spring protection zone and vulnerability mapping of selected springs in Sulaymaniyah area, Kurdistan, Iraq. Environmental Earth 
Sciences, $\quad 78(21), \quad 16$. doi:10.1007/s12665-019-8632-2

Al-Mezori, H. A., \& Hawrami, K. A. M. (2011). Evaluation of Microbial quality of the drinking water of Duhok province/Kurdistan region of Iraq. Paper presented at the 2011 2nd International Conference on Environmental Science and Development, IPCBEE, Singapore.

Alshatteri, A. H., \& Murad, R. A. (2015). comparison of chemical composition among different drinking water sources in Kalar city. Journal of Garmian University(2), 1001-1010.

Ameen, H. A. (2019). Spring water quality assessment using water quality index in villages of Barwari Bala, Duhok, Kurdistan Region, Iraq. Applied Water Science, 9(8), 176. doi:10.1007/s13201-019-1080-z

Association, A. P. H., Association, A. W. W., \& Federation, W. E. (2017). Standard methods for the examination of water and wastewater. In (pp. 1545). Washington, DC: American Public Health Association.

Aziz, S. Q. (2004). Seasonal Variation of Some Physical and Chemical Properties of Water and Wastewater in Erbil City. Journal of Duhok University, 7, 76-88.

Aziz, S. Q., \& Fakhrey, E. S. a. (2016). The effect of kawergosk oil refinery wastewater on surrounding water resources. ZANCO Journal of Pure and Applied Sciences (ZJPAS), 28(2), 656-667.

Aziz, S. Q., \& Maulood, Y. I. (2015). Contamination valuation of soil and groundwater source at anaerobic municipal solid waste landfill site.

Environ Monit Assess, 187(12), 755. doi:10.1007/s10661-015-4971-y

Baalousha, H. (2010). Assessment of a groundwater quality monitoring network using vulnerability mapping and geostatistics: A case study from Heretaunga Plains, New Zealand. Agricultural
Water Management, 97(2), 7. doi:https://doi.org/10.1016/j.agwat.2009.09.01 $\underline{3}$

Babir, G. B., \& Ali, S. M. (2016). Evaluation of Water Quality of Koi Sanjaq Basin, Erbil Governorate Northern Iraq. Iraqi Journal of Science, 57(1A), 15.

Barzinji, D. A., \& Ganjo, D. G. A. (2014). Assessment of the chemical quality of water in the Halabja-Sulaimani, Kurdistan Region of Iraq. Asian Journal of Water, Environment and Pollution, 11(2), 10.

Belkhiri, L., Tiri, A., \& Mouni, L. (2018). Assessment of Heavy Metals Contamination in Groundwater: A Case Study of the South of Setif Area, East Algeria. In Achievements and Challenges of Integrated River Basin Management (pp. 17-31): IntechOpen.

Bhatnagar, A., \& Sillanpää, M. (2011). A review of emerging adsorbents for nitrate removal from water. Chemical Engineering Journal, 168(2), 493-504.

doi:https://doi.org/10.1016/j.cej.2011.01.103

Bruvold, W. H., \& Ongerth, H. J. (1969). Taste quality of mineralized water. American Water Works Association, 61(4), 170-174. doi:10.1002/j.1551-8833.1969.tb03732.x

Canada, H., Water, F.-P.-T. C. o. D., \& Environment, F.-P.-T. C. o. H. a. t. (2019). Guidelines for Canadian drinking water quality-Summary table. In Summary Table (pp. 23). Ottawa, Ontario.: Healthy Environments and Consumer Safety Branch, Health Canada.

CDPH, C. D. o. P. H. (2013). Nitrate/nitrite in drinking water. (CCAMP-GAP). California Department of Public Health (CDPH)

Clarke, J. L. (2014). Structural lightweight aggregate concrete: CRC Press.

Cocchetto, D. M., \& Levy, G. (1981). Absorption of orally administered sodium sulfate in humans. 70(3), 331-333. doi:10.1002/jps.2600700330

dara.muhammad@koyauniversity.org,dara.hawez@gmail.com; Nashwan.shawkat@uod.ac: shuokr.aziz@su.edu.krd,shoker71@yahoo.com; juan.sabah@yahoo.com; 
Cotruvo, J. A., \& Bartram, J. (2009). Calcium and magnesium in drinking-water: public health significance: World Health Organization.

D'Agostino, V., Greene, E. A., Passarella, G., \& Vurro, M. (1998). Spatial and temporal study of nitrate concentration in groundwater by means of coregionalization. Environmental Geology, 36(3), 285-295. doi: $10.1007 / \mathrm{s} 002540050344$

Daham, F. A., Mustafa, B. Y., \& Abdulla, W. A. (1998). The quality evaluation of Erbil city ground water used for drinking and domestic purposes. ZANCO Journal of Pure and Applied Sciences (ZJPAS), 10(1), 36-41.

Domagalski, J. L., \& Johnson, H. (2012). Phosphorus and Groundwater: Establishing Links Between Agricultural Use and Transport to Streams (2012-3004). Retrieved from California:

Fingl, E. (1980). Laxatives and cathartics in Pharmacological basis of therapeutics. Mc.

Fisenne, I. M., \& Perry, P. M. (1985). Isotopic U concentration in human blood from New York City donors. Health Phys, 49(6), 1272-1275.

Gardi, S. Q. (2017). Environmental Impact Assessment of Erbil Dumpsite area - West of Erbil City-Iraqi Kurdistan Region. Journal of Tethys, 5(3), 24.

Gardi, S. Q. (2017). Integrated Use of Geoelectrical Resistivity and Geochemical Analysis to Assess the Environmental Impact on Soil and Groundwater at Erbil Dumpsite, West of Erbil City-Iraqi Kurdistan Region. ARO-The Scientific Journal of Koya University, 5(2), 19-31.

Gebrehiwot, A. B., Tadesse, N., \& Jigar, E. (2011). Application of water quality index to assess suitablity of groundwater quality for drinking purposes in Hantebet watershed, Tigray, Northern Ethiopia. ISABB Journal of Food Agricultural Sciences, 1(1), 9.
Hawrami, K., \& Mezuri, H. (2014). Assessing Risks to Human Health from Potentially Toxic Elements in Drinking Water of Duhok Province/ Kurdistan Region of Iraq. Journal of Environment Pollution Human Health, 2(2), 8. doi:DOI:10.12691/jephh-2-2-2

Health, N. I. o. (2020). Magnesium. Fact Sheet for Health Professionals. Retrieved from https://ods.od.nih.gov/factsheets/MagnesiumHealthProfessional/

Heathwaite, A. L., Burke, S. P., \& Bolton, L. (2006). Field drains as a route of rapid nutrient export from agricultural land receiving biosolids. Sci Total Environ, 365(1-3), 33-46. doi:10.1016/j.scitotenv.2006.02.033

Heathwaite, A. L., Dils, R. M., Liu, S., Carvalho, L., Brazier, R. E., Pope, L., Hughes, M., Phillips, G., \& May, L. (2005). A tiered risk-based approach for predicting diffuse and point source phosphorus losses in agricultural areas. Science of The Total Environment, 344(1), 225-239.

doi:https://doi.org/10.1016/j.scitotenv.2005.02 .034

Hem, J. D. (1985). Study and interpretation of the chemical characteristics of natural water (Vol. 2254). Washington DC.: Department of the Interior, US Geological Survey.

Hess, C. T., Michel, J., Horton, T. R., Prichard, H. M., \& Coniglio, W. A. (1985). The occurrence of radioactivity in public water supplies in the United States. Health Phys, 48(5), 553-586. doi:10.1097/00004032-198505000-00002

Islam, M., \& Patel, R. (2010). Synthesis and physicochemical characterization of $\mathrm{Zn} / \mathrm{Al}$ chloride layered double hydroxide and evaluation of its nitrate removal efficiency. Desalination, 256(1), 120-128. doi:https://doi.org/10.1016/j.desal.2010.02.003

Istok, J. D., \& Cooper, R. M. (1988). Geostatistics Applied to Groundwater Pollution. III: Global

dara.muhammad@koyauniversity.org,dara.hawez@gmail.com; Nashwan.shawkat@uod.ac: shuokr.aziz@su.edu.krd,shoker71@yahoo.com; juan.sabah@yahoo.com; shwana.manguri@uor.edu.krd ${ }^{1}$ Corresponding author Department of Civil Engineering, Faculty of Engineering, Koya University Koya KOY45, Kurdistan Region - F.R. Iraq 
Estimates. Journal of Environmental Engineering, ASCE, 114(4), 915-928. doi:doi:10.1061/(ASCE)0733-9372(1988)114: $4(915)$

Jadoon, S., Munir, S., \& Fareed, I. t. (2015). Evaluation of Drinking Water Quality in Erbil City Kurdistan, Region-Iraq. Journal of environment earth science, 5(21), 11.

Jang, C.-S., Chen, S.-K., \& Kuo, Y.-M. (2013). Applying indicator-based geostatistical approaches to determine potential zones of groundwater recharge based on borehole data. CATENA,

101 , doi:https://doi.org/10.1016/j.catena.2012.09.00 $\underline{3}$

Júnez-Ferreira, H. E., \& Herrera, G. S. (2013). A geostatistical methodology for the optimal design of space-time hydraulic head monitoring networks and its application to the Valle de Querétaro aquifer. Environ Monit Assess, 23. doi:10.1007/s10661-012-2808-5

Kareem, A., Merkel, B. J., \& Mustafa, O. (2015). Investigations of uranium and trace elements in groundwater of the Tanjero Area, Kurdistan Region, Iraq. Paper presented at the Uranium Past and Future Challenges.

Kareem, A., Mustafa, O., \& Merkel, B. (2018). Geochemical and environmental investigation of the water resources of the Tanjero area, Kurdistan region, Iraq. Arabian Journal of Geosciences, $11(16), \quad 10$. doi:10.1007/s12517-018-3825-7

Kilroy, G., \& Coxon, C. (2005). Temporal variability of phosphorus fractions in Irish karst springs. Environmental Geology, 47(3), 421-430. doi:10.1007/s00254-004-1171-4

La Touche, Y. D., Willis, D. L., \& Dawydiak, O. I. (1987). Absorption and biokinetics of $U$ in rats following an oral administration of uranyl nitrate solution. Health Phys, 53(2), 147-162. doi:10.1097/00004032-198708000-00005

Lanjwani, M. F., Khuhawar, M. Y., \& Khuhawar, T. M. J. (2019). Groundwater quality assessment of Shahdadkot, Qubo Saeed Khan and Sijawal Junejo Talukas of District Qambar Shahdadkot, Sindh. Applied Water Science, 10(1), 26. doi:10.1007/s13201-019-1098-2

Laslett, G. M. (1994). Kriging and Splines: An Empirical Comparison of their Predictive Performance in Some Applications. Journal of the American Statistical Association, 89(426), 391-400. doi:10.1080/01621459.1994.10476759

Majumdar, D., \& Gupta, N. (2000). Nitrate pollution of groundwater and associated human health disorders. Indian journal of environmental health, 42(1), 28-39.

Mehrjardi, R. T., Jahromi, M. Z., \& Heidari, A. (2008). Spatial Distribution of Groundwater Quality with Geostatistics (Case Study: Yazd-Ardakan Plain) 1. World Applied Sciences Journal(1), 09-17. doi:wasj4(1)/2p

Mogheir, Y., Singh, V. P., \& Pedroso de Lima, J. (2006). Spatial Assessment and Redesign of a Groundwater Quality Monitoring Network Using Entropy Theory, Gaza Strip, Palestine. Hydrogeology Journal, 14, 13. doi:10.1007/s10040-005-0464-3

Mohammed, K., Karim, S. H., \& Mohammed, S. A. (2018). The Influence of Waste Disposal Site on The Water and Soil Quality in Halabja Province, Kurdistan, Iraq. Science Journal of University of Zakho, 6(1), 10.

Morris, M. E., \& Levy, G. (1983). Absorption of Sulfate from Orally Administered Magnesium Sulfate in Man. Journal of Toxicology: Clinical Toxicology, 20(2), 107-114. doi:10.3109/15563658308990056

Moss, M. A. (1985). Chronic Low Level Uranium Exposure via Drinking Water-Clinical

dara.muhammad@koyauniversity.org,dara.hawez@gmail.com; Nashwan.shawkat@uod.ac: shuokr.aziz@su.edu.krd,shoker71@yahoo.com; juan.sabah@yahoo.com; shwana.manguri@uor.edu.krd'Corresponding author Department of Civil Engineering, Faculty of Engineering, Koya University Koya KOY45, Kurdistan Region - F.R. Iraq 
Investigations in Nova Scotia. Dalhousie University,

Mouser, P. J., \& Rizzo, D. M. (2004). Evaluation of Geostatistics for Combined Hydrochemistry and Microbial Community Fingerprinting at a Waste Disposal Site. In Critical Transitions in Water and Environmental Resources Management (pp. 1-11). Salt Lake City: American Society of Civil Engineers.

Narany, T. S., Ramli, M. F., Aris, A. Z., Sulaiman, W. N. A., \& Fakharian, K. (2014). Spatial assessment of groundwater quality monitoring wells using indicator kriging and risk mapping, Amol-Babol Plain, Iran. Water, 6(1), 18. doi:doi:10.3390/w6010068

Narsimha, A., \& Sudarshan, V. (2017). Contamination of fluoride in groundwater and its effect on human health: a case study in hard rock aquifers of Siddipet, Telangana State, India. Applied Water Science, 7(5), 2501-2512. doi:10.1007/s13201-016-0441-0

Nickson, R. T., McArthur, J. M., Shrestha, B., Kyaw-Myint, T. O., \& Lowry, D. (2005). Arsenic and other drinking water quality issues, Muzaffargarh District, Pakistan. Applied Geochemistry, 20(1), 55-68. doi:https://doi.org/10.1016/j.apgeochem.2004. $\underline{06.004}$

Oram, B. (2014). Sulfate, Hydrogen Sulfide, Sulfate Reducing Bacteria - How to Identify and Manage. Retrieved from https://water-research.net/index.php/sulfates

Organization, W. H. (2005). Uranium in drinking-water: background document for development of WHO guidelines for drinking-water quality. Retrieved from

Phillips, d. 1., Lee, e. H., Herstrom, a. a., Hogsett, w. E., \& Tingey, d. t. (1997). USE OF AUXILIARY DATA FOR SPATIAL INTERPOLATION OF OZONE EXPOSURE IN SOUTHEASTERN FORESTS. 8(1),
43-61.

doi:10.1002/(sici)1099-095x(199701)8:1<43:

Aid-env237>3.0.Co;2-g

Rajappa, B., Manjappa, S., Puttaiah, E., \& Nagarajappa, D. (2011). Physicochemical analysis of underground water of Harihara Taluk of Davanagere District, Karnataka, India. Advances in Applied Science Research, 2(5), 143-150.

Rao, N. S., Rao, P. S., Reddy, G. V., Nagamani, M., Vidyasagar, G., \& Satyanarayana, N. L. V. V. (2012). Chemical characteristics of groundwater and assessment of groundwater quality in Varaha River Basin, Visakhapatnam District, Andhra Pradesh, India. Environ Monit Assess, $\quad 184(8)$, 5189-5214. doi:10.1007/s10661-011-2333-y

Robinson, T. P., \& Metternicht, G. (2006). Testing the performance of spatial interpolation techniques for mapping soil properties. Computers and Electronics in Agriculture, 50(2), 97-108. doi:https://doi.org/10.1016/j.compag.2005.07. $\underline{003}$

Ross, A. C., Caballero, B. H., Cousins, R. J., Tucker, K. L., \& Ziegler, T. R. (2012). Modern nutrition in health and disease: Eleventh edition (Eleventh edition ed.): Wolters Kluwer Health Adis (ESP).

Salih, F. A., Kasem, A. O., Abdullah, T. H., Othman, N. F., \& Mina, M. B. (2015). Assessment of the quality of drinking water of Halabja City-Iraqi Kurdistan. Kirkuk University Journal /Scientific Studies (KUJSS), 10(3), 14.

Sarhat, A. R. (2017). Assessment of groundwater quality and its suitability for agricultural uses in Kifri. Journal of Garmian University, 4, 11. doi:10.24271/garmian.143

Saskatchewan. (2010). Alkalinity :For Private Water and Health Regulated Public Water Supplies.

dara.muhammad@koyauniversity.org,dara.hawez@gmail.com; Nashwan.shawkat@uod.ac: shuokr.aziz@su.edu.krd,shoker71@yahoo.com; juan.sabah@yahoo.com; shwana.manguri@uor.edu.krd ${ }^{1}$ Corresponding author Department of Civil Engineering, Faculty of Engineering, Koya University Koya KOY45, Kurdistan Region - F.R. Iraq 
Regina: Saskatchewan Ministry of Health Retrieved from www.SaskH20.ca

Sawyer, C. N. (1967). Chemistry for sanitary engineers. New York: McGraw-Hill.

Service, U. S. P. H. (1962). Public health service drinking water standards (Vol. 2): US Government Printing Office.

Sharma, A. D., \& Rishi, M. S. (2016). Presence of Uranium in Groundwater of Punjab: An Overview. In N. J. Raju (Ed.), Geostatistical and Geospatial Approaches for the Characterization of Natural Resources in the Environment (pp. 231-236). Cham: Springer International Publishing.

Smith, S., \& Rau, J. L. (1982). Ground water hydrology for water well contractors. [Worthington, Ohio]: National Water Well Association.

Smith, W., \& Crombie, I. (1987). Coronary heart disease and water hardness in Scotland - Is there a relationship? Journal of epidemiology and community health, 41, 227-228. doi:10.1136/jech.41.3.227

Tate, C., \& Arnold, K. F. (1990). Health and aesthetic aspects of water quality. In Water Quality and Treatment (pp. 63-156). New York,: McGraw-Hill Inc.

Tinti, A. (2017). Water Resources Management in the Kurdistan Region of Iraq. Retrieved from Sulaimani, Iraq 46001:

Toma, J. J. (2006). Physico-Chemical and Bacteriological Analysis for Ground Water Wells in Ainkawa, Erbil, Iraq. Paper presented at the Proc. 4 th Int. Con. Biol. Sci. (Botany).

Toma, J. J., Assad, Z., S., \& Baez, D., R. . (2013). Water Quality Assessment of Some Well Water in Erbil City by Quality Index, Kurdistan Region-Iraq. Journal of Advanced Laboratory Research in Biology, 4(4), 6.

Umer, M. I., Abduljabar, P. A., \& Hamid, N. A. (2018). Assessment of Ground Water Pollution by Heavy Metals and Anions in Kwashe Industrial Area, Duhok City, Kurdistan Region. Iraq. Paper presented at the IOP Conference Series: Materials Science and Engineering.

Umer, M. I., Qaseem, N. M. A., Rashed, M., \& Al-Barwary, A. (2020). Seasonal variation of some chemical quality indicators of drinking water from selected villages around Zakho district Kurdistan region Iraq. Paper presented at the AIP Conference Proceedings Baghdad.

USEPA. (1985). National primary drinking water regulations; synthetic organic chemicals, inorganic chemicals and microorganisms; proposed rule. In (pp. 219): US Environmental Protection Agency:Federal Register.

USEPA. (2018). 2018 Edition of the Drinking Water Standards and Health Advisories Tables. In (pp. 12). Washington, DC: U.S. Environmental Protection Agency.

Waller, R. M. (1988). Ground water and the rural homeowner: US Department of of the Interior/Geological Survey.

Weber, D. D., \& Englund, E. J. (1994). Evaluation and comparison of spatial interpolators II. Mathematical Geology, 26(5), 589-603. doi:10.1007/BF02089243

WHO. (2003). Background document for development of WHO guidelines for drinking-water quality. In Total dissolved solids in drinking-water. (pp. 8). Geneva: World Health Organization.

WHO. (2017). Guidelines for drinking-water quality: first addendum to the fourth edition. In (pp. 631): World Health Organization.

Withers, P. J. A., \& Haygarth, P. M. (2007). Agriculture, phosphorus and eutrophication: a European perspective. 23(s1), 1-4. doi:10.1111/j.1475-2743.2007.00116.x

Wrenn, M. E., Durbin, P. W., Howard, B., Lipsztein, J., Rundo, J., Still, E. T., \& Willis, D. L.

dara.muhammad@koyauniversity.org,dara.hawez@gmail.com; Nashwan.shawkat@uod.ac: shuokr.aziz@su.edu.krd,shoker71@yahoo.com; juan.sabah@yahoo.com; shwana.manguri@uor.edu.krd ${ }^{1}$ Corresponding author Department of Civil Engineering, Faculty of Engineering, Koya University Koya KOY45, Kurdistan Region - F.R. Iraq 
(1985). Metabolism of ingested $\mathrm{U}$ and Ra.

Health Phys, 48(5), 601-633. doi:10.1097/00004032-198505000-00004

Yİlmaz, E., \& Koç, C. (2014). Physically and chemically evaluation for the water quality criteria in a farm on Akcay. Journal of Water Resource and Protection, 6(2), 63-67. doi:10.4236/jwarp.2014.62010

Yousuf, R. M., \& Abullah, K. O. (2011). Measurement of uranium and radon Concentrations in resources of water from
Sulaimany Governorate-Kurdistan region-iraq. ARPN Journal of Science Technology, 3(6), 7. Zangana, M., Ibraheem, F., \& Khoshnaw, F. (2014). Hammam Jalli as Thermal Spring. Academic Journal of Science, 3(2), 12.

Zimmerman, D., Pavlik, C., Ruggles, A., \& Armstrong, M. P. (1999). An Experimental Comparison of Ordinary and Universal Kriging and Inverse Distance Weighting. Mathematical Geology, 31(4), 375-390. doi:10.1023/A:1007586507433

dara.muhammad@koyauniversity.org,dara.hawez@gmail.com; Nashwan.shawkat@uod.ac: shuokr.aziz@su.edu.krd,shoker71@yahoo.com; juan.sabah@yahoo.com; shwana.manguri@uor.edu.krd ${ }^{1}$ Corresponding author Department of Civil Engineering, Faculty of Engineering, Koya University Koya KOY45, Kurdistan Region - F.R. Iraq 